\title{
Every Cloud has a Silver Lining: Cleansing Effects of the Portuguese Financial Crisis
}

Dias, Daniel A. and Carlos Robalo Marques

Please cite paper as:

Dias, Daniel A. and Carlos Robalo Marques (2019). Every

Cloud has a Silver Lining: Cleansing Effects of the Portuguese

Financial Crisis. International Finance Discussion Papers 1250.

https://doi.org/10.17016/IFDP.2019.1250

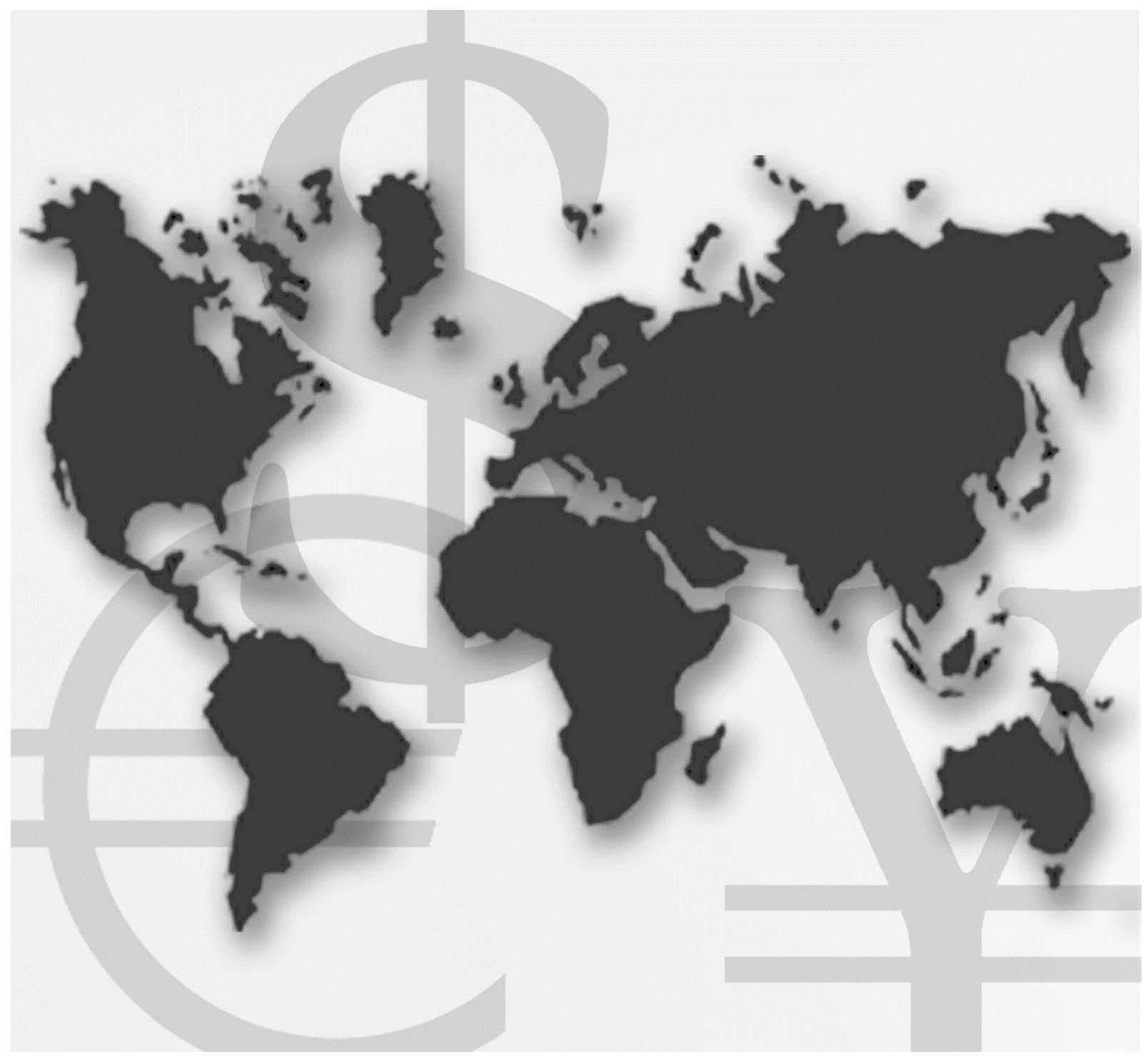

\section{International Finance Discussion Papers}

Board of Governors of the Federal Reserve System

Number 1250

June 2019 
Board of Governors of the Federal Reserve System

International Finance Discussion Papers

Number 1250

June 2019

\title{
Every Cloud has a Silver Lining: Cleansing Effects of the Portuguese Financial Crisis
}

\author{
Daniel A. Dias
}

Carlos Robalo Marques

NOTE: International Finance Discussion Papers are preliminary materials circulated to stimulate discussion and critical comment. References to International Finance Discussion Papers (other than an acknowledgment that the writer has had access to unpublished material) should be cleared with the author or authors. Recent IFDPs are available on the Web at www.federalreserve.gov/pubs/ifdp/. This paper can be downloaded without charge from the Social Science Research Network electronic library at www.ssrn.com. 


\title{
Every cloud has a silver lining: Cleansing effects of the Portuguese financial crisis*
}

\author{
June 3, 2019
}

\begin{abstract}
Using firm-level data, this paper shows that the Portuguese financial crisis was a period of intensified productivity-enhancing reallocation. Aggregate productivity gains, both in manufacturing and services, came from relatively higher contributions of entering and exiting firms and from reallocation of resources between surviving firms. At the microlevel, the crisis reduced the probability of survival for high- and low-productivity firms, but it hit low-productivity firms disproportionately harder. We also found important heterogeneous effects across economic sectors regarding input reallocation that underline the importance of using data for the entire economy whenever similar studies are conducted.
\end{abstract}

JEL classification: D24, E32, L25, O47

Key words: Productivity, firm-level data, entry, exit, survival.

${ }^{*}$ The authors thank, without implicating, the Editor Jonathan Temple and two anonymous Reviewers for very helpful suggestions. The analyses, opinions and findings of this paper represent the views of the authors, which are not necessarily those of Banco de Portugal, the Eurosystem, the Board of Governors of the Federal Reserve System or of any other person associated with the Federal Reserve System. 


\section{Introduction}

This paper studies the effect of the 2011-2012 Portuguese financial crisis on productivity dynamics. More specifically, we investigate whether this crisis had a cleansing effect by improving the allocation of resources in the economy from low- to high-productivity firms, or a scarring effect by exacerbating market imperfections and driving highproductivity firms out of the market.

The empirical evidence on this issue is mixed, with conclusions varying across countries. For instance, Foster et al. (2001) for the United States, and Casacuberta and Gandelman (2015) for Uruguay, conclude that crises were times of productivity enhancing reallocation, while Nishimura et al. (2005) for Japan, Hallward-Driemeier and Rijkers (2013) for Indonesia, and Eslava et al. (2015) for Colombia find scarring effects of recessions stemming from credit market imperfections. More recently, Foster et al. (2016) find that the intensity of reallocation fell rather than rose in the United States during the Great Recession (2007-2009) and that the reallocation that took place was less productivity-enhancing than in prior recessions.

An important limitation of these contributions, is that, due to data availability, the empirical evidence is restricted to the manufacturing sector, thereby precluding inferences for the total economy. The manufacturing sector contributes less than 20 percent to total GDP and has very distinct characteristics from the service sector, which accounts for around 80 percent of total GDP in most countries. Thus, if there are important differences between the two sectors regarding the impact of crises, those studies that are only based on the manufacturing sector may be providing a biased view of the effect of crises on aggregate productivity dynamics.

Our paper contributes to literature by bringing forward novel evidence on the consequences of financial crises on resource reallocation and productivity, involving the various sectors of the economy. Using microlevel data for the Portuguese economy, we investigate how the patterns of resource reallocation changed during the Portuguese financial crisis in terms of intensity and the extent to which it was productivity-enhancing 
and long-lasting. Given that we have data for the whole economy, an important contribution of our paper is that it contrasts the evidence for the different sectors, namely manufacturing and service sectors. More specifically, this paper addresses the following questions: Did the patterns of resource reallocation change during the 2011-2012 financial crisis? Were these changes productivity enhancing and long-lasting? Were they common or different across sectors (manufacturing versus services)? Is there evidence of a negative impact of credit constraints on productivity dynamics?

In order to answer these questions, we study the dynamics of two measures of productivity - labour productivity computed from value added and total factor productivity (TFP) computed from gross output - during the pre-crisis, crisis and recovery periods. Following the literature, we decompose productivity according to the contributions of the different types of firms (surviving, entering and exiting firms) and estimate regressions on exit, entry and input growth to evaluate the implications of the crisis on input reallocation.

Our results suggest that the 2011-2012 financial crisis in Portugal had, overall, a cleansing effect both in manufacturing and services. At the aggregate or macro level, we find higher positive contributions for productivity growth of the between-firm and exiting components, during the crisis, together with a lower negative contribution of entry. Even though the evidence regarding the cross-firm effects is mixed, the contribution of total reallocation for productivity growth increased, suggesting that, overall, the crisis was a period of intensified productivity-enhancing reallocation, both in manufacturing and services.

At the firm-level, we find that the crisis reduced the probability of survival for highand low-productivity firms but hit low-productivity firms disproportionately harder, in line with the cleansing hypothesis. However, the protective impact of productivity increased significantly more in relative terms in manufacturing than in the service sector. In the manufacturing sector, new firms also emerge as relatively more productive during and after the crisis, in contrast with the service sector. As for reallocation of inputs, we 
find a strengthening of the correlation between productivity and employment growth, but a weakening of the correlation between productivity and capital growth during the crisis. Importantly, these aggregate results reflect different sectoral developments, with the manufacturing sector exhibiting significant cleansing effects regarding employment and capital reallocation, and the service sector, mainly nontradable services, exhibiting negative or scarring effects regarding capital reallocation. We believe that the sector-level heterogeneity regarding input reallocation reflects the specific features of the Portuguese financial crisis, which affected mostly nontradable services, and the distortions or frictions prevailing in each sector of activity, namely different levels of competition and different input adjustment costs.

We also find that the cleansing effect documented for the crisis period was, to a large extent, a short-lived phenomenon. With the exception of the contribution of exiting firms for productivity growth, possibly due to lagged effects of the crisis, the increase in productivity contributions recorded for other components during the crisis, vanished or faded away during the recovery period.

Finally, we find that the probability of exiting increased significantly for firms operating in more financially dependent industries belonging to the nontradable sub-sector, but there is no evidence of an attenuation effect, i.e., the increase in the probability of exit, during the crisis, is not correlated with productivity. In other words, we did not find evidence that the cleansing impact, regarding exiting firms, was significantly attenuated by the presence of increased credit constraints and/or credit forbearance during the crisis.

The rest of the paper is organised as follows. Section 2 briefly describes the theoretical literature on the impact of crises on productivity dynamics, and characterizes the Portuguese financial crisis. Section 3 describes the data used and explains how the most important variables were constructed. Sections 4 and 5 present and discuss the main empirical results regarding the cleansing or scarring effects of the financial crisis separating the macro and microlevel approaches, and section 6 summarizes the 
main findings. Details on the definition, estimation, interpretation and aggregation of the firm-level productivity measures used in the paper, can be found in Appendices A and $\mathrm{B}$, and details on the construction of firm-level real capital stock are presented in Appendix C.

\section{Related literature and context}

\section{$2.1 \quad$ Related literature}

According to Schumpeter 1939, 1942), business cycles are driven by a process of creative destruction, by which innovative, high-productivity firms drive relatively unproductive firms out of business. Theoretical models of this hypothesis assume that recessions promote a more efficient allocation of resources by cleansing out less efficient production arrangements and redirecting resources into relatively more productive uses (see Caballero and Hammour (1994) and Mortensen and Pissarides (1994)).

However, the presence of market distortions may attenuate this cleansing effect or even reverse it, so that crises may become a period of counterproductive destruction, by hampering adjustments and protracting the recovery process. Such distortions may arise from many factors. Caballero and Hammour (1996) highlight some distortions or market failures that may have disruptive effects on job creation and job destruction, such as search inefficiencies or bargaining problems in the labour market, which reduce the impact of recessions on resource reallocation. Barlevy (2002) claims that while recessions hasten the destruction of less efficient businesses, they also make more difficult the transition of workers into more productive uses (on-the-job search is procyclical). This feature gives rise to a sullying effect that works against the conventional cleansing effect. In a similar vein, Collier and Goderis (2009) argue that regulations that delay the speed of firm exit may hinder the creative destruction process, while Haltiwanger et al. (2008) show that distortionary labour market regulations, like employment protection legislation, by raising labour adjustment costs and reducing job turnover, may 
prevent an efficient reallocation of workers. In turn, Ouyang (2009) assumes that recessions affect disproportionately infant businesses, which tend to appear as unproductive in the short run, but have the potential to reveal high productivity in the long run. By destroying young firms, recessions may scar the economy, by preventing new and innovative firms from reaching their potential. This scarring effect may offset the conventional cleansing effect. Kehrig (2015) suggests a model in which the fall in factor prices during recessions increases the probability of surviving for low-productivity firms and thus mitigates the cleansing effect.

Importantly, in the presence of credit market distortions, recessions may hurt efficient firms disproportionately, as they have higher financing needs. Barlevy (2003) shows that the presence of financial constraints may reverse the conventional cleansing effect, because reallocation may direct resources from more efficient to less efficient uses. In contrast, Osotimehin and Pappadà (2017) suggest a model where credit frictions reduce the intensity of the cleansing effect but do not reverse it. ${ }^{1}$

In short, economic theory suggests that whether recessions have a cleansing or a scarring effect depends on the type and importance of distortions prevailing in the economy. In the absence of distortions, recessions are expected to promote a more efficient allocation of resources by cleansing out less efficient firms and redirecting resources into relatively more productive uses. But, the presence of market distortions, especially in the labour and capital markets, may hinder the creative destruction process by delaying the speed of firm exit or preventing an efficient reallocation of resources. To the extent that the importance of market distortions varies across sectors of economic activity (e.g., manufacturing and services), the effects of recessions are also expected to vary and, in the limit, these may even result in a cleansing effect for some sectors and a scarring effect for others.

\footnotetext{
${ }^{1}$ The key difference between these two models is the way they model the exit decisions of firms that are subject to credit restrictions. In the first paper, it is assumed that high-productivity firms are more likely to be subject to credit restrictions and thus more likely to exit the market, while the second accounts for the role of profitability in the exiting decision of the firm, so that high-productivity firms have a lower probability of falling below the net-worth exiting threshold.
} 


\subsection{The Portuguese financial crisis}

Between 1995 and 2001 the Portuguese economy benefited from the Eurozone convergence in the run-up to the introduction of the euro, undergoing a structural transformation, shifting away from manufacturing and towards services $2^{2}$ However, this came at the expense of lower competitiveness and higher indebtedness. By 2002, investment and GDP had stagnated, but large current account and headline budget deficits remained, resulting in general government debt breaching 60\% of GDP in 2004 .

The whole situation deteriorated further in the following years, also as a consequence of the 2008 international financial crisis. By 2010, the interest rates on longterm Portuguese government bonds started rising, a few months after the same had happened in Greece. By April 2011 the Portuguese government was forced to ask for external assistance. One month later, the Troika, comprised of the International Monetary Fund, the European Commission, and the European Central Bank, approved a memorandum of understanding with the Portuguese government in exchange for a rescue package (The economic and financial assistance programme) ${ }^{3}$ This package "guaranteed the financing of the Portuguese economy for a period that allows implementing a gradual and structural correction of the imbalances in the public finances and external accounts, in addition to preparing and implementing the structural reforms required to reverse the main structural impediments to the economy's growth potential" (Annual Report, Bank of Portugal, 2011).

Against this background, in 2011 and 2012 there were unprecedented fiscal consolidation efforts, based essentially on tax increases and a strong contraction of public expenditure (namely public sector wage bill and investment), accompanied by a significant increase in the degree of lending restrictiveness by the Portuguese banks (given the virtual absence of external market funding). As a consequence, in this period,

\footnotetext{
${ }^{2}$ Portugal was one of the first countries to adopt the euro on 1 January 1999, together with other 10 European countries (Germany, France, Italy, Spain, the Netherlands, Ireland, Austria, Belgium, Finland and Luxembourg).

${ }^{3}$ See Blanchard (2007), Reis (2013) and Blanchard and Portugal (2017) for detailed analyses of the evolution of the Portuguese macroeconomy in the run-up to the Eurozone crisis.
} 


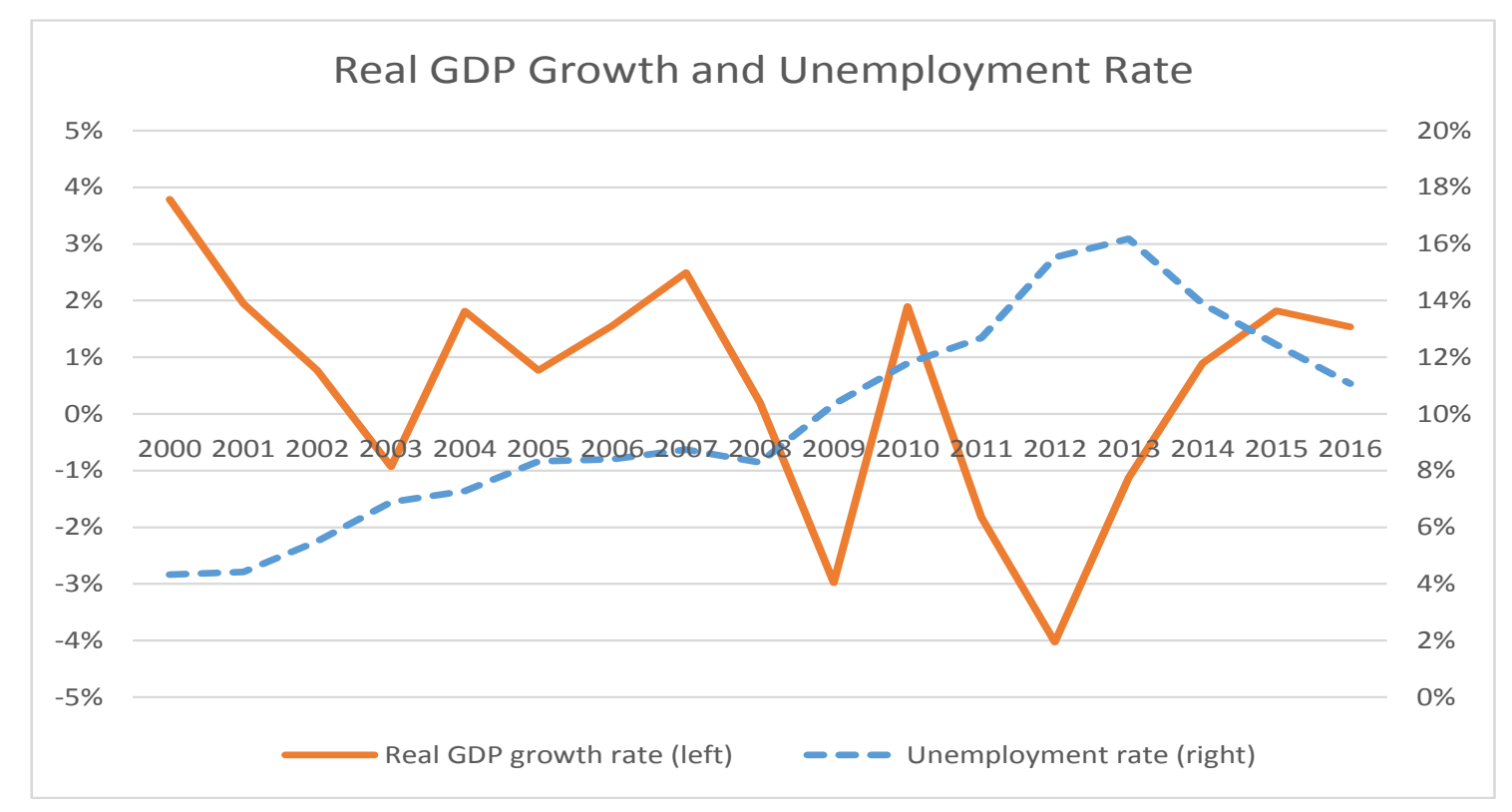

Figure 1: Economic growth and unemployment in Portugal

a sharp decline in domestic demand (private consumption, public consumption and investment) was observed, GDP decreased substantially and the unemployment rate recorded a large increase (see Figure 1). Only in the second half of 2013 did the economy start to show the first signs of a recovery. Indeed, although GDP declined, in annual average terms, by -1.1 per cent in 2013 , it underwent a market intra-annual recovery that led GDP to stand, in the last quarter of the year, 1.7 percent above the level recorded in the last quarter of 2012 (Economic Bulletin, April 2014, Bank of Portugal). The unemployment rate, however, started to decline only in 2014.

Some important features of the Portuguese recession, which include the negative demand shock implied by the fiscal consolidation efforts and the increase in the degree of lending restrictiveness, are expected to have a bearing on the findings of this paper, by their potential heterogeneous impacts on firms and sectors of activity. The sharp decline in domestic demand affected differently the tradable and nontradable sectors of the economy. During this period, exports of goods and services, in contrast to the strong contraction in the rest of the economy, displayed robust growth, even above external demand, implying a significant gain in the exports market shares. On average, 
while domestic demand decreased around 6 percent per year in 2011 and 2012, exports increased, on average, around 5 percent per year in this period, contributing positively to GDP growth..$^{4}$ The increase in the degree of lending restrictiveness (banks were required to reduce loan-to-deposit ratios to sustainable levels) is also expected to have affected firms and sectors differently. There is evidence that the increase in bank lending restrictiveness hit the nontradable sector, including construction, real estate and trade (retail and wholesale) disproportionately hard (Annual Report, 2012, Bank of Portugal) $!^{5}$

\section{The data}

In this paper we use firm-level balance sheet data that draw on annual information for Portuguese firms reported under the Informação Empresarial Simplificada (IES), covering the period 2006 to 2015. IES data exist from 2006 onwards and covers virtually the universe of Portuguese non-financial firms. The almost universal coverage of IES emerges from the fact that it is the system through which firms report mandatory information to the tax administration and the statistical authorities like the Instituto Nacional de Estatistica (INE) (the Portuguese Statistics Institute), and the Banco de Portugal (the Portuguese central bank). The data provide very detailed information on

\footnotetext{
${ }^{4}$ The positive performance of exports during the recession period, also recorded in other euroarea countries, like Ireland and Spain, has been explained in the literature by a negative relationship between domestic demand and exports: in periods of economic stress, firms are more willing to pay the sunk costs for entering a new market abroad (survival driven exports). See, for instance, Belke et al. (2015), Eichenbaun et al. (2016) and Esteves and Prades (2018).

${ }^{5}$ Between 2011 and 2014 several labour- and product-market structural reforms were implemented in Portugal. The labour-market reforms reduced severance payments, the duration and level of unemployment benefits, and simplified individual and collective dismissal procedures. Product-market reforms included privatizations, the simplification of licensing procedures, the phasing out of regulated tariffs on electricity and gas, increased competition in retail trade, reduced barriers to entry in professional services, etc. These reforms are not expected to have had a significant impact on the findings of this paper for the crisis period (2011-2012), because most of them, namely the ones regarding the labour market, were implemented only on the second half of 2012. In contrast, if we believe that these reforms had the desired effect, the results for the recovery period may already include some effects of the reforms on productivity dynamics. Ideally, we would like to tease out the effects of the reforms because this information could be useful for policy making purposes, but we do not have a good identification strategy. For further details on the structural reforms implemented see, for instance, Eichenbaun et al. (2016) and OECD (2017).
} 
the firms' balance sheets and income statements. From this dataset, we get information on firm's gross output, value added, consumption of intermediate inputs, labour costs, employment, gross fixed capital formation, capital depreciations, and the book values of the capital stock.

Before using the data, we clean the dataset by dropping firms that do not report strictly positive figures for gross output (production), labour costs, employment, capital stock, intermediate consumption and value added. After cleaning the data, we are left with a number of firms that varies between 240,030 in 2006 and 247,575 in 2015.

Table 1 records the relative importance of the main sectors of activity in our dataset (agriculture, manufacturing, construction, utilities and services) in terms of gross output (GO), gross value added (GVA) and employment (Emp). Note the small contribution of agriculture for total employment and value added (around 2 percent), while manufacturing contributes around 25 percent and the service sector around 60 percent ${ }^{6}$ Note also that the construction sector lost about 40 percent of its contribution to aggregate value added between 2006 and 2015, reflecting the structural crisis underwent by this sector since the early 2000's. Table 1 also distinguishes between tradable and nontradable services.7 Tradable services contribute about 12 percent to total value added and correspond to about 20 percent of the service sector.

In order to obtain estimates for real gross output, real value added and real intermediate consumption, we use industry-level price indices. These price indices for the manufacturing sector were built with information from the disaggregated manufacturing production price index (obtained from INE). For the non-manufacturing industries, for which no price index was available, we used alternative deflators depending on the

\footnotetext{
${ }^{6}$ According to information from the National Accounts, in 2010, agriculture, manufacturing, construction, utilities and services contribute 2.3, 13.8, 6.2, 3.9 and 73.8 percent for aggregate GDP, respectively. Thus, if anything, our dataset appears to be slightly skewed towards manufacturing and against the service sector. We note, however, that in contrast to the National Accounts, services in our dataset do not include information of the government sector, the financial sector and self-employment.

${ }^{7}$ The distinction among tradable and nontradable industries follows Amador and Soares (2012). They define as tradable the industries for which the export to sales ratio is above 15 percent, along with all the manufacturing industries.
} 
Table 1: Relative importance of each sector in the dataset

(Percentage)

\begin{tabular}{|l|r|r|r|r|r|r|r|r|r|}
\hline \hline & \multicolumn{3}{|c|}{2006} & \multicolumn{3}{c|}{2010} & \multicolumn{3}{c|}{2015} \\
\hline \hline & GO & GVA & Emp. & GO & GVA & Emp. & GO & GVA & Emp. \\
\hline \hline Agric. & 2.0 & 2.1 & 2.1 & 2.1 & 1.9 & 2.2 & 2.5 & 2.2 & 2.6 \\
Manuf. & 32.9 & 25.6 & 27.9 & 31.5 & 23.1 & 24.0 & 34.8 & 25.1 & 24.4 \\
Const. & 15.0 & 11.5 & 13.2 & 13.9 & 10.3 & 12.4 & 7.6 & 7.0 & 8.7 \\
Utilities & 3.3 & 4.4 & 0.4 & 2.7 & 4.0 & 0.4 & 6.4 & 4.4 & 0.5 \\
Services & 46.8 & 56.4 & 56.3 & 49.9 & 60.6 & 61.0 & 48.6 & 61.4 & 63.8 \\
\hline T. serv. & 10.3 & 10.3 & 8.8 & 11.8 & 12.1 & 9.9 & 12.4 & 13.4 & 10.7 \\
NT. serv. & 36.6 & 46.2 & 47.5 & 38.1 & 48.5 & 51.2 & 36.3 & 48.0 & 53.1 \\
\hline \hline
\end{tabular}

Note: Agriculture also includes forestry, fishing, mining and quarrying; the utilities sector includes electricity, gas and water services.

type of industry (disaggregated items of the consumer price index and the investment goods deflator). In order to compute the real stock of capital, we used the perpetual inventory method, with a special adjustment factor for the first year of the sample (2006). This approach is similar to that used by Foster et al. (2016) and the details of the procedure can be found in Appendix C.

The dataset also includes information on the firm's main industry of operation based on NACE classification (Rev. 2.1 and Rev. 3) both at 3- and 5-digit disaggregation level. However, the exercises in our paper are conducted with industries defined at the 3-digit NACE code (Rev. 2.1) because we do not have information on prices at a higher disaggregation level, and also because the number of firms at a 5-digit classification will be very small for many industries, making it impossible to estimate the corresponding production functions. After dropping industries with less than 10 firms (to avoid estimation problems), we are left with 202 industries defined at the 3digit NACE code classification - 16 for agriculture (including forestry, fishing, mining and quarrying), 101 for manufacturing and 85 for services (including construction and utilities). 


\section{Cleansing or scarring effects of the crisis? Macro- level evidence}

The literature outlined above yields competing testable predictions at both the macro and microlevel for the cleansing or scarring effects of recessions. To test whether the Portuguese crisis had a cleansing or a scarring effect on productivity, we follow closely the approaches suggested in Hallward-Driemeier and Rijkers (2013) and Foster et al. (2016). In this section we investigate the macrolevel or aggregate implications. The microlevel implications are investigated in the next section.

In order to investigate the macrolevel implications, we decompose aggregate productivity growth into the contributions of the different groups of firms (survivors, entrants and exiters) to see whether there is evidence of a significant change in the contribution of these groups to aggregate productivity growth during and after the crisis. We start by introducing the relevant productivity decomposition.

\subsection{Decomposing aggregate productivity growth}

In line with the literature, we define the logarithm of aggregate productivity at time $t$ as a share weighted average of the logarithm of firm-level productivities:

$$
P_{t}=\sum_{i} \theta_{i t} p_{i t}
$$

where $p_{i t}$ stands for the logarithm of firm $i$ productivity and the shares $\theta_{i t} \geq 0$ sum to 1 . The variable of interest is the change in aggregate productivity over time $\Delta P_{t}=$ $P_{t}-P_{t-1}$, or, more generally, $\Delta_{r} P_{t}=P_{t}-P_{t-r}$. Because firm-level productivities are measured in logs, $\Delta P_{t}$ represents a percentage change. ${ }^{8}$ The literature has used different choices both for $p_{i t}$ and the share weights $\theta_{i t}$. In Appendix B, we discuss the alternatives and justify the choices used in our empirical application.

\footnotetext{
${ }^{8}$ Note that, as defined in (1), aggregate productivity, $P_{t}$, is the log of a weighted geometric mean of firm-level productivities.
} 
To assess whether crises have a cleansing or a scarring effect at the aggregate level, we use a decomposition of aggregate productivity growth, which results from a combination of the Melitz and Polanec (2015) and the Foster et al. (2001) decompositions. Let firms at time $t$ be categorized as survivors $\left(S_{t}\right)$, entrants $\left(E_{t}\right)$ and exiters $\left(X_{t}\right)$, and define $\theta_{k t}=\sum_{i \in k} \theta_{i t}$ as the aggregate market share and $P_{k t}=\sum_{i \in k}\left(\theta_{i t} / \theta_{k t}\right) p_{i t}$ as the average aggregate productivity of category $\mathrm{K}$ of firms $\left(\mathrm{K}=S_{t}, E_{t}, X_{t}\right)$. Melitz and Polanec (2015) show that we can express aggregate productivity, given by equation (1), for periods 1 and 2 (for instance), as a function of the aggregate share and aggregate productivity of surviving, entering and exiting firms, where $\theta_{i 1}=0$ for entrants and $\theta_{i 2}=0$ for exiters:

$$
\begin{aligned}
& P_{1}=\theta_{S 1} P_{S 1}+\theta_{X 1} P_{X 1}=P_{S 1}+\theta_{X 1}\left(P_{X 1}-P_{S 1}\right) \\
& P_{2}=\theta_{S 2} P_{S 2}+\theta_{E 2} P_{E 2}=P_{S 2}+\theta_{E 2}\left(P_{E 2}-P_{S 2}\right)
\end{aligned}
$$

From these equations we can compute the aggregate productivity change $\Delta P=$ $P_{2}-P_{1}$ in terms of the contribution of each group of firms:

$$
\Delta P=\left(P_{S 2}-P_{S 1}\right)+\theta_{E 2}\left(P_{E 2}-P_{S 2}\right)+\theta_{X 1}\left(P_{S 1}-P_{X 1}\right)
$$

This decomposition features a contribution of entering firms that increases with the aggregate productivity of entrants, $P_{E 2}$, a contribution of exiting firms that increases with lower aggregate productivity of exiters, $P_{X 1}$, and an aggregate contribution of surviving firms that increases with the difference $P_{S 2}-P_{S 1}$. The contribution of surviving firms can be decomposed further, and there are several possibilities. For example, Melitz and Polanec (2015) suggest decomposing the contribution of surviving firms using the well-known Olley-Pakes decomposition (Olley and Pakes (1996)).9 Alterna-

\footnotetext{
${ }^{9}$ Applying the Olley-Pakes decomposition to the surviving firms we get:$$
\Delta P=\Delta \bar{P}_{S}+\Delta \operatorname{Cov}_{S}+\theta_{E 2}\left(P_{E 2}-P_{S 2}\right)+\theta_{X 1}\left(P_{S 1}-P_{X 1}\right)
$$

where $\operatorname{Cov}_{S}=\sum_{i \in S}\left(\theta_{i t}-\overline{\theta_{S}}\right)\left(p_{i t}-\bar{P}_{S}\right)$, and $\bar{P}_{S}=\left(1 / N_{s}\right) \sum_{i \in S} p_{i t}$ and $\bar{\theta}_{S}=1 / N_{s}$ denote the
} 
tively, which we find more useful for the purpose of this paper, we can follow a similar approach to that of Baily et al. (1992), Griliches and Regev (1995), and Foster et al. (2001) and decompose the contribution of the surviving firms as follows:

$$
\Delta P=\sum_{i \in S} \mu_{i 1} \Delta p_{i 2}+\sum_{i \in S} p_{i 1} \Delta \mu_{i 2}+\sum_{i \in S} \Delta \mu_{i 2} \Delta p_{i 2}+\theta_{E 2}\left(P_{E 2}-P_{S 2}\right)+\theta_{X 1}\left(P_{S 1}-P_{X 1}\right)
$$

where $\mu_{i t}=\left(\theta_{i t} / \theta_{S t}\right), t=1,2 \sqrt{10}$ We note that this equation, keeps the expressions for the contributions of entry and exit in equation (2) unaltered. The first term in this decomposition represents the "within effect", i.e., the contribution of within-firm productivity changes of surviving or continuing firms, weighted by initial market shares. The second term represents the "between effect", i.e., the contribution of market share reallocation to productivity growth, weighted by the initial productivity level. The third term represents the "cross effect" (covariance type effect). The fourth and fifth terms represent the contribution of entry (entry effect) and exiting firms (exit effect) for productivity growth, respectively.

It is important to stress that decomposition (3), as decomposition (2), has an important advantage over alternative decompositions suggested in the literature. In particular, it eliminates the biases in the measurement of entry and exit contributions (and hence also in the contribution of surviving firms), that are a feature of other decomposition methods, such as the ones suggested in Griliches and Regev (1995) and Foster et al. (2001)). Melitz and Polanec (2015) argue that equation (2) more accurately reflects the contributions of each group of firms in the sense that we can

unweighted firm productivity mean and the mean market share among surviving firms, respectively. This equation denotes the so-called Dynamic Olley-Pakes decomposition (DOLP) as suggested in Melitz and Polanec (2015). The first two terms in the equation corresponding to the Olley-Pakes decomposition show that changes in productivity over time for surviving firms are simply given by the change in the unweighted mean, $\Delta \bar{P}_{S}$ and the change in "covariance" term, $\Delta$ Cov $_{S}$. This provides a natural way of decomposing productivity changes into a component that captures shifts in the productivity distribution (changes in the unweighted mean) and a component that captures market share reallocations (changes in the "covariance" term).

${ }^{10}$ The decomposition, regarding the contribution of surviving firms, follows directly from equation (2) by noting that

$P_{S 2}-P_{S 1}=\sum_{i \in S}\left(\theta_{i 2} / \theta_{s 2}\right) p_{i 2}-\sum_{i \in S}\left(\theta_{i 1} / \theta_{s 1}\right) p_{i 1}=\sum_{i \in S} \mu_{i 2} p_{i 2}-\sum_{i \in S} \mu_{i 1} p_{i 1}=\sum_{i \in S} \mu_{i 1} \Delta p_{i 2}+$ $\sum_{i \in S} p_{i 1} \Delta \mu_{i 2}+\sum_{i \in S} \Delta \mu_{i 2} \Delta p_{i 2}$. 
relate each group contribution to a specific counterfactual scenario as follows: the contribution of surviving firms is simply the aggregate productivity that would have been observed in absence of entry and exit. The contribution of entry, $\theta_{E 2}\left(P_{E 2}-P_{S 2}\right)$, is the change in aggregate productivity, $\Delta P$, generated by adding/removing the group of entrants. Similarly the contribution of exit, $\theta_{X 1}\left(P_{S 1}-P_{X 1}\right)$, is the change in aggregate productivity generated by adding/removing the group of exiting firms. Thus, entrants generate positive productivity growth if and only if they have higher productivity, $P_{E 2}$, than the surviving firms, $P_{S 2}$, in the same time period when the entry occurs $(\mathrm{t}=2)$. Exiters generate positive productivity growth if and only if they have lower productivity, $P_{X 1}$, than the remaining surviving firms, $P_{S 1}$, in the same time period when exit occurs $(t=1) \cdot 11$

Under the cleansing hypothesis, we should expect an increase in the contribution of exit and entry for productivity growth, as well as an increase in resource reallocation regarding surviving firms (relatively more productive firms gaining market share) and a stronger correlation between changes in productivity and changes in market share (firms that experience larger productivity losses suffer larger reductions in market share). Thus, in terms of decomposition (3), if crises have a cleansing effect, one would expect to see a higher contribution from exit and entry. We should also expect an increase in the between and cross terms, and thus the relative contribution of within-firm adjustment to aggregate productivity growth to be proportionately smaller than during normal times. In practice, we may have a situation in which not all of these four terms increase their relative contribution to productivity growth. To account for such a possibility, we define "total reallocation" as the sum of the "between", "cross", "entry"

\footnotetext{
${ }^{11}$ The main distinguishing feature of the Melitz and Polanec (2015) decomposition compared to the Griliches and Regev (1995) and Foster et al. (2001) decompositions stems from the fact that they use different reference productivity levels for entrants and exiters. In Griliches and Regev (1995) both entry and exit are compared to $\bar{P}=\left(P_{1}+P_{2}\right) / 2$, while in Foster et al. (2001) entry and exit are compared to aggregate productivity in period $1, P_{1}$. By contrast, in Melitz and Polanec (2015) the reference productivity levels for entrants, $P_{S 2}$, differs from the reference productivity level for exiters, $P_{X 1}$. Suppose, for example, that productivity is growing so that $P_{S 2}>P_{S 1}$. The reference productivity levels $P_{1}$ in Foster et al. (2001) and $\bar{P}$ in Griliches and Regev (1995) are below $P_{S 2}$, leading to an overmeasurement of the contribution of entry for both decompositions, and hence an undermeasurement of the contribution for the two remaining groups of firms.
} 
and "exit" components, and label as "cleansing effect" the situation in which the relative contribution for aggregate productivity growth of total reallocation increases during the crisis period, compared to normal times. Under these circumstances, we also characterize the crisis as a time of intensified productivity-enhancing reallocation.

By contrast, under the scarring hypothesis, stemming from credit market constraints, we should expect firms more dependent on credit to be more affected. During financial crises credit market distortions reduce the efficiency of resource reallocation through reduced bank lending to profitable projects that require more capital. Under these circumstances, we should witness the exit of high-productivity firms (because they are financially constrained). This would show up in a negative or reduced contribution of exit to productivity growth in equation (3). Banks may also forbear bad debtors delaying the process of downsizing or firm death, in order to protect their balance sheets (zombie lending or evergreening of loans), thereby hindering one of the mechanisms through which productivity growth arises. In this case, one might also not witness an increase in the between- and/or the cross-term (employment and/or capital reallocation not reacting to changes in productivity). Besides credit constraints, other distortions prevailing in the economy, such as labour market regulations, search inefficiencies and pro-cyclicality of on the job search may also contribute to reduce or even reverse an otherwise expected cleansing effect (see subsection 2.1). For the purpose of the present paper, we characterize as "scarring effect" the situation in which the relative contribution for productivity growth of total reallocation decreases during the crisis period, compared to normal times.

In order to conduct our aggregate productivity decomposition exercises, we look at two alternative productivity measures, $p_{i t}$, to be used in equation (3): a labour productivity measure defined on value added and a total factor productivity measure (TFP) defined on gross output. More specifically, the labour productivity measure is defined as the log difference of real value added and employment (number of employees), while TFP is computed as the estimated residuals of a three input Cobb-Douglas 
production function defined on real gross output. ${ }^{12}$ Firm-level productivity measures are aggregated at the industry, sectoral or total economy level using, as weights, the shares of log employment for labour productivity, and of log input mix for TFP. ${ }^{13}$ This way, we account for the presence of measurement errors in the weights, which may have important implications for the estimates of aggregate productivity measures. The details on the definitions, estimation, interpretation and aggregation of our productivity measures are discussed at length in Appendices A and B.

\subsection{Resource reallocation before, during and after the crisis.}

Following the discussion above, we start by investigating the behavior of entrants, exitors and survivors using the decomposition in equation (3). Given the above described economic developments, we consider three distinct time sub-periods: "pre-crisis" (20062010), "crisis" (2011-2012) and "recovery" (2013-2015). The annual average contributions for aggregate productivity growth for these three sub-periods are recorded in Table 2

Let us start by looking at the effect of entry and exit on aggregate productivity growth ${ }^{14}$ According to the discussion above, if the crisis has a cleansing effect we should expect a higher contribution from exit and possibly of entry, and thus an increase in the net-entry contribution. From Table 2, we can see that there is an increase in the net entry contribution during the crisis for both productivity measures. In particular,

\footnotetext{
${ }^{12}$ The production functions are estimated at the industry level using the Levinsohn-Petrin estimator (see Levinsohn and Petrin (2003)), to account for the endogeneity of the regressors. Besides the Levinsohn-Petrin estimator, we tried other methods that also account for endogeneity of the regressors as the ones suggested in Wooldridge (2009) and Ghandi et al. (2016). However, both methods turned out to exhibit strong estimation convergence issues. Thus, as robustness checks, we computed TFP using OLS estimates and input shares (under the CRS assumption). The qualitative conclusions obtained in this paper for these alternative TFP measures do not depend on the estimation method used.

${ }^{13}$ The input-mix is defined as a geometric mean of inputs using estimated factor elasticities.

${ }^{14}$ The estimates of our productivity measures for the utilities sector are very erratic, displaying huge annual variations that can be as big as +30 percent (for TFP in 2007) or -30 percent (for value-added labour productivity in 2015). In accumulated terms, between 2006 and 2015, the numbers also vary across our productivity measures beyond any sensible thresholds $(+15$ percent for TFP and -82 percent for value-added labour productivity) making it impossible to draw any interesting conclusions. For this reason, in what follows figures for the "Total economy" exclude the contribution of this sector.
} 
Table 2: Productivity decompositions: average annual contributions

(Total economy)

\begin{tabular}{|c|c|c|c|c|c|c|}
\hline \hline & \multicolumn{3}{|c|}{ Labour Productivity } & \multicolumn{3}{c|}{ TFP } \\
\cline { 2 - 7 } Components & $\begin{array}{c}\text { Pre-crisis } \\
(2006-2010)\end{array}$ & $\begin{array}{c}\text { Crisis } \\
(2011-2012)\end{array}$ & $\begin{array}{c}\text { Recovery } \\
(2013-2015)\end{array}$ & $\begin{array}{c}\text { Pre-crisis } \\
(2006-2010)\end{array}$ & $\begin{array}{c}\text { Crisis } \\
(2011-2012)\end{array}$ & $\begin{array}{c}\text { Recovery } \\
(2013-2015)\end{array}$ \\
\hline \hline$(1)$ & $(2)$ & $(3)$ & $(4)$ & $(5)$ & $(6)$ & $(7)$ \\
\hline \hline Surviving firms & 0.56 & -2.68 & 2.14 & -0.22 & -1.42 & 1.06 \\
Within & 1.78 & -2.13 & 3.27 & 0.10 & -1.08 & 1.61 \\
Between & 2.00 & 2.34 & 1.98 & 0.50 & 0.53 & 0.54 \\
Cross & -3.22 & -2.89 & -3.11 & -0.82 & -0.87 & -1.09 \\
\hline Net-entry & -1.20 & 0.16 & -0.56 & -1.03 & 0.06 & 0.07 \\
Entry & -3.03 & -2.61 & -3.28 & -1.49 & -0.93 & -1.19 \\
Exit & 1.84 & 2.77 & 2.72 & 0.46 & 0.99 & 1.26 \\
\hline Total reallocation & -2.42 & -0.39 & -1.69 & -1.35 & -0.28 & -0.48 \\
\hline Total change & -0.64 & -2.51 & 1.57 & -1.24 & -1.35 & 1.13 \\
\hline \hline
\end{tabular}

Note: Labour productivity refers to value added per employee, with the shares of log employment as weights; TFP refers to gross output, with the shares of log input mix as weights. Total reallocation is the sum of the between, cross and net-entry contributions. These results exclude the contribution of utilities (electricity, gas and water services).

the average annual net-entry contribution for TFP growth is negative between 2006 and 2010 (-1.03), but slightly positive (0.06 percent) for the 2011-2012 period, so that there is an average annual increase of 1.09 percentage points $(\mathrm{pp})$ in the net-entry contribution to TFP growth. Similar numbers are obtained for labour productivity. In turn, the increase in net-entry contribution reflects a large increase in the positive contribution of exit, but also a significant reduction in the negative contribution of entry, suggesting that productivity of entrants increased during the crisis relatively to that of survivors. Interestingly, in the case of labour productivity the contribution of net-entry turns negative again in the recovery period, while the TFP contribution remains about the same, as in the crisis period. This difference may stem from the fact that new firms have less capital. While TFP takes this fact into account, labour productivity does not and indicates lower productivity.

We note also that the between-firm component increased during the crisis, for the two productivity measures, with a more significant impact in case of labour productivity. Thus, if anything, the evidence suggests that during the crisis relatively more productive firms, among survivors, exhibited higher input growth, as one could expect under the cleansing hypothesis. As for the cross effect, we get a modest positive change during the crisis for labour productivity $(+0.33)$ and a small negative change for TFP 
(-0.05). Together, the total impact of reallocation regarding surviving firms (change in the between- and the cross-firm components) is positive for labour productivity $(+0.67)$ and virtually null for TFP (-0.02) suggesting that the negative contribution of reallocation before the crisis may have been attenuated during the crisis. Similarly to the net-entry contribution, there is some evidence of a deterioration in the contribution of the between and cross terms during the recovery period, suggesting that the increase in the importance of reallocation for productivity growth was a short-lived phenomenon. We also note that there is a significant decline in the contribution of the within effect during the crisis, that is followed by a strong recovery in the recovery period, as could be expected.

Finally, from Table 2, we conclude that "total reallocation" (despite being negative due to the cross and entry effects) increased significantly its contribution to productivity growth during the crisis period, compared to the pre-crisis period. We interpret this result as evidence of an overall cleansing effect of the 2011-2012 financial crisis.

Table 3: Labour productivity decomposition: average annual contributions (Manufacturing and Services)

\begin{tabular}{|c|c|c|c|c|c|c|}
\hline \hline & \multicolumn{3}{|c|}{ Manufacturing } & \multicolumn{3}{c|}{ Services } \\
\cline { 2 - 7 } Components & $\begin{array}{c}\text { Pre-crisis } \\
(2006-2010)\end{array}$ & $\begin{array}{c}\text { Crisis } \\
(2011-2012)\end{array}$ & $\begin{array}{c}\text { Recovery } \\
(2013-2015)\end{array}$ & $\begin{array}{c}\text { Before } \\
(2006-2010)\end{array}$ & $\begin{array}{c}\text { Crisis } \\
(2011-2012)\end{array}$ & $\begin{array}{c}\text { Recovery } \\
(2013-2015)\end{array}$ \\
\hline \hline$(1)$ & $(2)$ & $(3)$ & $(4)$ & $(5)$ & $(6)$ & $(7)$ \\
\hline \hline Surviving firms & 1.67 & -1.30 & 1.93 & 0.76 & -3.48 & 2.48 \\
Within & 2.14 & -1.17 & 2.25 & 2.12 & -2.64 & 3.87 \\
Between & 1.19 & 1.31 & 1.18 & 2.40 & 2.58 & 2.18 \\
Cross & -1.66 & -1.44 & -1.50 & -3.76 & -3.42 & -3.57 \\
\hline Net-entry & -0.04 & 0.67 & -0.23 & -1.57 & -0.21 & -0.89 \\
Entry & -1.94 & -1.93 & -2.40 & -3.39 & -2.90 & -3.66 \\
Exit & 1.90 & 2.60 & 2.17 & 1.82 & 2.69 & 2.77 \\
\hline Total reallocation & -0.51 & 0.54 & -0.55 & -2.93 & -1.05 & -2.28 \\
\hline Total change & 1.63 & -0.63 & 1.70 & -0.81 & -3.69 & 1.59 \\
\hline \hline
\end{tabular}

Note: Labour productivity refers to value added per employee; the weights are the shares of log employment; The service sector does not include construction nor utilities (electricity, gas and water services).

As discussed earlier, the effect of the crisis may be different in different sectors of the economy. To see whether the crisis affected manufacturing and services differently, we replicate the analysis of Table 2 for each sector. The corresponding results for 
Table 4: TFP decomposition: average annual contributions

(Manufacturing and Services)

\begin{tabular}{|c|c|c|c|c|c|c|}
\hline \hline & \multicolumn{3}{|c|}{ Manufacturing } & \multicolumn{3}{c|}{ Services } \\
\cline { 2 - 7 } Components & $\begin{array}{c}\text { Pre-crisis } \\
(2006-2010)\end{array}$ & $\begin{array}{c}\text { Crisis } \\
(2011-2012)\end{array}$ & $\begin{array}{c}\text { Recovery } \\
(2013-2015)\end{array}$ & $\begin{array}{c}\text { Pre-crisis } \\
(2006-2010)\end{array}$ & $\begin{array}{c}\text { Crisis } \\
(2011-2012)\end{array}$ & $\begin{array}{c}\text { Recovery } \\
(2013-2015)\end{array}$ \\
\hline \hline$(1)$ & $(2)$ & $(3)$ & $(4)$ & $(5)$ & $(6)$ & $(7)$ \\
\hline \hline Surviving firms & 0.37 & -0.72 & 0.68 & -0.21 & -1.36 & 1.19 \\
Within & 0.54 & -0.61 & 1.04 & 0.05 & -1.10 & 1.81 \\
Between & 0.66 & 0.86 & 0.80 & 0.60 & 0.66 & 0.56 \\
Cross & -0.83 & -0.97 & -1.16 & -0.86 & -0.92 & -1.18 \\
\hline Net-entry & -0.22 & 0.35 & 0.85 & -0.98 & 0.62 & 0.14 \\
Entry & 0.95 & 0.89 & 1.12 & -2.33 & -1.43 & -1.92 \\
Exit & -1.17 & -0.54 & -0.27 & 1.35 & 2.05 & 2.06 \\
\hline Total reallocation & -0.39 & 0.24 & 0.49 & -1.24 & 0.36 & -0.48 \\
\hline Total change & 0.15 & -0.37 & 1.53 & -1.19 & -0.74 & 1.33 \\
\hline \hline
\end{tabular}

Note: TFP refers to gross output with weights given by the shares of log "input mix". The service sector does not include construction nor utilities (electricity, gas and water services).

labour productivity and TFP are shown in Tables 3 and 4 , respectively. These two tables show that the cleansing effect is present in both the manufacturing and the service sectors. The net-entry contribution and the between-firm contribution increase during the crisis (especially the former) in the two sectors and for the two productivity measures. Again, for the cross-firm contribution the evidence is somewhat mixed: it increases in both sectors in terms of labour productivity, but decreases in terms of TFP. Comparing total reallocation during and before the crisis, we conclude that the crisis period brought about an increase in the contribution of resource reallocation for productivity growth both in the manufacturing and the service sectors (0.63 pp and 1.60 pp, respectively for TFP). Again, we interpret these results as evidence of an overall cleansing impact of the crisis in both sectors. If we look further into the service sector, we also find evidence of a cleansing effect both in tradable and nontradable services. ${ }^{15}$ Regarding the duration of the cleansing impact, we note that there are some differences between the two sectors. For example, while the contribution for productivity growth of total reallocation, as measured by TFP, still increases during the recovery period for manufacturing it declines for services, even turning negative, due to the negative

\footnotetext{
${ }^{15}$ In the case of TFP, the change in total reallocation between the pre-crisis and the crisis periods is $1.06 \mathrm{pp}$ for tradable services and $1.75 \mathrm{pp}$ for nontradable services. See Tables A1 and A2 in Appendix $\mathrm{D}$
} 
contribution of nontradable services (Table A2, in Appendix D). In summary, the aggregate and sectoral analysis suggests that the three sectors - manufacturing and tradable and nontradable services - contributed to the overall cleansing impact of the crisis, but the intensified productivity enhancing reallocation documented during the crisis period, faded away more quickly in nontradable services.

As a robustness test, we also computed the decompositions for labour productivity using employment shares as weights (some exercises carried out showed that employment is not very much affected by outliers), and for TFP using the shares of log nominal gross output as weights ${ }^{16}$ The decompositions are recorded in Tables A3 (aggregate economy), A4 and A5 (sectoral disaggregation) in Appendix D. The conclusions on the cleansing impact of the crisis are qualitatively similar to the ones obtained from Tables 2, 3 and 4, for both labour productivity and TFP: there is an increase in the relative contribution for productivity growth of total reallocation during the crisis, reflecting the increase in the between-firm and net-entry contribution and the absence of a clear-cut impact of the cross-firm contribution (positive for TFP, but negative for labour productivity) ${ }^{17}$

\footnotetext{
${ }^{16}$ See Appendix B for a discussion on the use of gross output shares as alternative weights to compute aggregate TFP.

${ }^{17}$ For TFP, note also that the use of gross output shares as weights in Tables A3 and A5 increases the contributions of the cross effects and decreases the contributions of the between and within effects, in comparison with the use of the input-mix shares in Tables 2 and 4 . For the aggregate economy, the cross-firm contributions and the between-firm contributions even reverse signs. A similar phenomenon involving the contributions for these two components may be found, for instance, in Foster et al. (2001), where employment and gross output shares are used as weights to compute aggregate TFP. In order to understand these results recall that the production function implies that $\Delta \ln \left(T F P_{i t}\right)=$ $\Delta \ln \left(Q_{i t}\right)-\Delta \ln \left(I M_{i t}\right)$, where $Q_{i t}$ and $I M_{i t}$ stand for the gross output and the input mix respectively. Thus, changes in $Q_{i t}$ stemming from shocks, other than input shocks, such as measurement errors in $Q_{i t}$, demand shocks or other supply shocks imply, tantamount, a similar change in measured TFP, generating an upward bias in the correlation between $\Delta \ln \left(T F P_{i t}\right)$ and $\Delta \ln \left(Q_{i t}\right)$, and contributing to a positive cross effect, when gross output shares are used as weights. The opposite holds for shocks to inputs that have no implications on the level of output. For instance, measurement errors in the inputs, including re-evaluations or large amortizations of the capital stock, generate a downward bias in the correlation between $\Delta \ln \left(T F P_{i t}\right)$ and $\Delta \ln \left(I M_{i t}\right)$, contributing to a negative cross effect, when input shares are used as weights.
} 


\section{Cleansing or scarring effects of the crisis? Micro- level evidence}

We now investigate the microlevel testable implications of the cleansing or scarring hypothesis of the crisis. Models of firm dynamics by Jovanovic (1982), Hopenhayn (1992) and Ericson and Pakes (1995) provide a framework for heterogeneous firm dynamics models, where firms are subject to idiosyncratic productivity, demand and cost shocks, which impact their growth and survival.

In line with these models, under the cleansing hypothesis, we should expect recessions, which can be thought of as large negative aggregate demand, cost or productivity shocks, to accelerate the exiting of low-productivity firms, resulting in a stronger association between survival and productivity. In addition, the correlation between productivity and employment and/or capital growth should strengthen because less productive firms should shrink more than more productive firms, in response to negative shocks. Finally, there may also be an increase in the productivity of entering firms, relative to that of incumbent firms.

By contrast, under the scarring hypothesis, one should expect recessions to weaken these relationships, so that the link between productivity, exit, entry and input growth should be attenuated. As noted above, during financial crises credit market distortions may reduce the efficiency of resource reallocation through reduced bank lending to profitable projects that require more capital. Under these circumstances, we may witness the exit of high-productivity firms (because they are financially constrained) and an attenuation of the link between productivity and survival. Banks may also forbear bad debtors delaying the process of downsizing or firm death, thereby hindering one of the mechanisms through which productivity growth arises. These distortions in the capital market, in isolation or in combination with other distortions/frictions prevailing in the economy, especially in the input markets (see subsection 2.1), may weaken the correlation between productivity and input growth. 
To test these two hypotheses at the micro level, we follow Foster et al. (2016) and estimate simple linear models linking firm exit, input growth, or firm entry to productivity. Our empirical model is given by:

$$
y_{i, t+1}=\lambda+\beta p_{i t}+\delta c_{t}+\gamma c_{t} \cdot p_{i t}+\mu r_{t}+\theta r_{t} \cdot p_{i t}+\epsilon_{i t}
$$

The left-hand-side variable, $y_{i, t+1}$, is a dummy variable in the firm exit and entry regressions (taking the value 1 if firm $i$ exits or enters the market in the following period and 0 otherwise) and a quantitative variable in the input (employment and capital) growth regressions. ${ }^{18}$ The regressor $c_{t}$ is a dummy variable for the crisis years, $r_{t}$ is a dummy variable for the recovery period, and $p_{i t}$ stands for the log of productivity. This specification is very general, as all the parameters of the model are allowed to vary over time, delivering estimates for the pre-crisis (2007-2010), crisis (2011-2012) and the recovery (2013-2015) periods.

In the case of exit, $y_{i, t+1}$ is a dummy variable equal to 1 if firm $i$ exits the market in period $(t+1)$. For this case, $\beta$ is expected to be negative, because more productive firms should be less likely to exit. Under the hypothesis that crises have a cleansing impact, i.e., intensify the creative destruction process, $\gamma$ should be negative. By contrast, if $\gamma$ is positive, we conclude that the crisis has a hampering effect on the process of creative destruction. As the process of creative destruction may take time, $\theta$ and $\mu$ allow us to compare the change in the protective effect of productivity in the crisis and the recovery periods.

To asses if employment or capital growth become more strongly associated with productivity during the crisis, we estimate equation (4) where now $y_{i, t+1}$ represents employment or capital growth between period $t$ and $t+1$. Under the hypothesis that crises have a cleansing impact, i.e., intensify reallocation of inputs from low-productivity to high-productivity firms, $\gamma$ should be positive. By contrast, if $\gamma$ is negative we conclude

\footnotetext{
${ }^{18}$ As timing is important, we note that in the models we explore the determinants of exit and input growth from $t$ to $t+1$ based on firm level productivity in period $t$.
} 
that the crisis reduced the importance of productivity as a determinant of firm growth. Again, $\theta$ and $\mu$ allow us to investigate whether the process of intensified input reallocation stopped immediately after the crisis, or continued over the recovery period. To investigate whether the crisis increased the productivity of entrants relatively to that of incumbent firms, we estimate a variant of equation (4) that relates the probability of firm entry to productivity, i.e., where $y_{i, t+1}$ is a dummy variable which equals 1 if firm $i$ is an entrant, and is zero otherwise. Finally, to uncover potential scarring effects of the crisis associated with changing credit conditions, we estimate a generalization of equation (4) that additionally includes an industry-level indicator of financial dependence.

In this section, we restrict the analysis to TFP. We view TFP as a better measure of productivity than labour productivity, because it takes into account usage of all factors of production. Moreover, this concept of productivity is the relevant one for firm's decision making and thus for resource reallocation.

\section{$5.1 \quad$ Exit}

The estimation results for exiting firms are in Tables 5 8 . Tables 5 and 6 also include the input growth regressions results, which we comment in the next subsection. We start by focusing on exiting firms for the aggregate economy (Table 5 , second column). Under the cleansing hypothesis, recessions are expected to accelerate the exit of lowproductivity firms, resulting in a stronger association between firm productivity and survival, at the microlevel.

From Table 5 we see that the coefficient associated with the log of productivity $\left(p_{i t}\right)$ is negative, meaning that productivity has a protective impact on firms, increasing their probability of survival: one percent increase in TFP reduces the probability of exiting by 2.21 percent. Of primary interest, we also find that the relationship between productivity and firm survival is enhanced during the crisis (the interaction effect is negative and significant): the negative impact of productivity on exit increased 0.22 percent in 
magnitude, which means that one percent increase in TFP reduces the probability of exit by 2.43 percent during the crisis, i.e., around 10 percent higher than in normal times. The coefficient of the crisis dummy variable, $\left(c_{t}\right)$, is also positive and statistically different from zero, so that during the crisis there was an increase of 2.64 percent in the probability of exit, independent of productivity levels. This result combined with the negative coefficient of the interaction term implies a significant cleansing effect, because the probability of exit of low-productivity firms increased disproportionately during the crisis 19 This increase in the protective effect of productivity is still present in the recovery period (the coefficient of $r_{t} \cdot p_{i t}$ is negative and statistically significant), even though not as strongly as in the crisis period. This finding is fully consistent with the increase in the contribution of exit for productivity growth documented in section 420

\footnotetext{
${ }^{19}$ Given the well-known difficulty in obtaining accurate measures of productivity during crises periods, an obvious question is whether the results presented above are dependent on some influential observations or outliers in the data. Thus, as a robustness test we also estimated a model where productivity is ranked by terciles. The idea is that the resulting rank is immune to outliers and measurement errors in productivity. In particular, being ordinal, the rank protects against the impact of measurement errors that are common to all firms in an industry, such as using inappropriate deflators. The results of the estimated model are qualitatively similar to the ones in column (2) of Table 5 . In particular they show that $i$ ) the probability of exit is negatively correlated with TFP: firms in the first tercile have a significantly higher probability of exiting than firms in the second and third terciles and ii) all firms are more likely to exit during the crisis, but firms in the lowest productivity tercile suffered the largest increase in the probability of exit (2.53 pp compared to $0.76 \mathrm{pp}$ in the second tercile and $0.48 \mathrm{pp}$ in the third tercile). Thus, this alternative regression corroborates the above result that the crisis reduced the probability of survival of high- and low-productivity firms, but hit low-productivity firms disproportionately harder, in line with the cleansing hypothesis. The full set of results is available upon request.

${ }^{20}$ Note, however, that we are not estimating weighted regressions sot that the conclusions from the models estimated in this section need not be fully in line with the evidence on the contributions from the previous section. Moreover, the increase in the contribution of entry or exit in section 4 during the crisis does not require an increase on the average productivity of exiting or entering firms, but just an increase of the difference between the average productivity of exiting (or entering) firms and that of the surviving firms.
} 
Table 5: Reallocation and TFP

(Total Economy)

\begin{tabular}{|c|c|c|c|c|c|}
\hline Covariates & Exit & $\begin{array}{c}\text { Empl. } \\
\text { growth } \\
\text { (Survivors }+ \\
\text { exiters) }\end{array}$ & $\begin{array}{c}\text { Empl. } \\
\text { growth } \\
\text { (Survivors } \\
\text { only) }\end{array}$ & $\begin{array}{c}\text { Capital } \\
\text { growth } \\
\text { (Survivors }+ \\
\text { exiters) }\end{array}$ & $\begin{array}{c}\text { Capital } \\
\text { growth } \\
\text { (Survivors } \\
\text { only) }\end{array}$ \\
\hline (1) & $(2)$ & $(3)$ & (4) & $(5)$ & $(6)$ \\
\hline constant & $\begin{array}{l}0.16766 \\
(72.58)^{* * *}\end{array}$ & $\begin{array}{c}-0.17518 \\
(-58.59)^{* * *}\end{array}$ & $\begin{array}{c}-0.15920 \\
(-48.69)^{* * *}\end{array}$ & $\begin{array}{c}-0.15349 \\
(-27.17)^{* * *}\end{array}$ & $\begin{array}{c}-0.11024 \\
(-18.31)^{* * *}\end{array}$ \\
\hline$p_{i t}$ & $\begin{array}{l}-0.02214 \\
(-41.00)^{* * *}\end{array}$ & $\begin{array}{l}0.04333 \\
(61.03)^{* * *}\end{array}$ & $\begin{array}{l}0.04256 \\
(55.27)^{* * *}\end{array}$ & $\begin{array}{l}0.05889 \\
(43.95)^{* * * *}\end{array}$ & $\begin{array}{l}0.05375 \\
(37.33)^{* * *}\end{array}$ \\
\hline$c_{t}$ & $\begin{array}{l}0.02637 \\
(18.57)^{* * * *}\end{array}$ & $\frac{-0.04578}{(-26.31)^{* * *}}$ & $\frac{-0.04314}{(-25.23)^{* * *}}$ & $\frac{-0.09539}{(-30.87)^{* * *}}$ & $\frac{-0.08058}{(-28.47)^{* * *}}$ \\
\hline$c_{t} \cdot p_{i t}$ & $\begin{array}{c}-0.00215 \\
(-6.94)^{* * *}\end{array}$ & $\begin{array}{c}0.00134 \\
(3.44)^{* * *}\end{array}$ & $\underset{(2.32)^{* *}}{0.00088}$ & $\begin{array}{c}-0.00124 \\
(-1.77)^{*}\end{array}$ & $\begin{array}{c}-0.00274 \\
(-4.22)^{* * *}\end{array}$ \\
\hline$r_{t}$ & $\begin{array}{l}0.01917 \\
(13.69)^{* * *}\end{array}$ & $\begin{array}{c}-0.00265 \\
(-1.74)^{*}\end{array}$ & $\begin{array}{c}-0.01594 \\
(-9.38)^{* * *}\end{array}$ & $\begin{array}{c}-0.06187 \\
(-21.94)^{* * *}\end{array}$ & $\begin{array}{c}-0.06265 \\
(-21.60)^{* * *}\end{array}$ \\
\hline$r_{t} \cdot p_{i t}$ & $\underset{(-5.81)^{* * *}}{-0.00180}$ & $-\frac{0.00040}{(-1.18)}$ & $-\begin{array}{c}0.00003 \\
(-0.08)\end{array}$ & $\underset{(-3.38)^{* * *}}{-0.00216}$ & $\frac{-0.00286}{(-4.33)^{* * *}}$ \\
\hline Observations & $1,821,361$ & $2,044,591$ & $1,672,489$ & $2,044,591$ & $1,672,489$ \\
\hline Industry FE & Yes & Yes & Yes & Yes & Yes \\
\hline
\end{tabular}

Note: Exit, employment and capital growth are measured from period t to period $t+1$. Regression for exit is a linear probability model where exit $=1$ if the firm is in the dataset in period $\mathrm{t}$ but not in period $\mathrm{t}+1$; $p_{i t}$ stands for log firm-level TFP; $c_{t}$ is a dummy variable equal to one for years 2011-2012 and $r_{i t}$ is a dummy variable equal to one for years 2013-2015. T-statistics (in parentheses) are obtained using standard errors clustered by industry; ${ }^{* * *} p<0.01$, $* *<0.05$, and ${ }^{*} p<0.10$.

As discussed before, because our data cover the whole economy we can shed light on whether a crisis can have different effects on different sectors. As such, to investigate this issue, we estimate equation (4) by sectors of activity. The results are presented in Table 6, column (2), for manufacturing, tradable services and nontradable services. A first noticeable result is that the importance of protective role of TFP (coefficient of $\left.p_{i t}\right)$ ) is about the same in the two service sub-sectors (tradable and nontradable services) and three times as larger in these two sub-sectors compared to the manufacturing sector. A second important result is that there is a significant cleansing effect of the crisis in the three sectors, but the protective effect of TFP increased significantly more in relative terms in the manufacturing sector than in the two service subsectors: the negative impact of productivity on exit increased about 37 percent in manufacturing (about $0.33 \mathrm{pp}$ ), compared to between 7 and 9 percent in the nontradable and tradable 
Table 6: Reallocation and TFP

(Sectors of activity)

\begin{tabular}{|c|c|c|c|c|c|}
\hline Sectors & Exit & $\begin{array}{c}\text { Empl. } \\
\text { growth } \\
\text { (Survivors }+ \\
\text { exiters) }\end{array}$ & $\begin{array}{c}\text { Empl. } \\
\text { growth } \\
\text { (Survivors } \\
\text { only) }\end{array}$ & $\begin{array}{c}\text { Capital } \\
\text { growth } \\
\text { (Survivors }+ \\
\text { exiters) }\end{array}$ & $\begin{array}{c}\text { Capital } \\
\text { growth } \\
\text { (Survivors } \\
\text { only) }\end{array}$ \\
\hline$(1)$ & $(2)$ & $(3)$ & $(4)$ & $(5)$ & $(6)$ \\
\hline \multicolumn{6}{|l|}{ Manufacturing: } \\
\hline$\overline{p_{i t}}$ & $\frac{-0.00897}{(-7.48)^{* * *}}$ & $\begin{array}{l}0.03313 \\
(17.91)^{* * *}\end{array}$ & $\underset{(16.48)^{* * * *}}{0.03231}$ & $\underset{(16.57)^{* * *}}{0.04856}$ & $\begin{array}{l}0.04440 \\
(14.75)^{* * *}\end{array}$ \\
\hline$c_{t}$ & 0.02170 & $\begin{array}{c}-0.04599 \\
(-12.20)^{* * *}\end{array}$ & $\frac{-0.04299}{(-12.14)^{* * *}}$ & $\frac{-0.08145}{(-14.12)^{* * *}}$ & $\frac{-0.07407}{(14.75)^{* * *}}$ \\
\hline$c_{t} \cdot p_{i t}$ & $\begin{array}{c}-0.00329 \\
(-5.22)^{* * *}\end{array}$ & $\underset{(5.53)^{* * *}}{0.00459}$ & $\begin{array}{c}0.00323 \\
(4.19)^{* * *}\end{array}$ & $\begin{array}{c}0.00194 \\
(1.47)\end{array}$ & $\begin{array}{c}0.00152 \\
(1.30)\end{array}$ \\
\hline$r_{t}$ & $\underset{(4.82)^{* * *}}{0.01341}$ & $\underset{(2.02)^{* *}}{0.00676}$ & $\begin{array}{c}-0.00955 \\
(-2.69)^{* * *}\end{array}$ & $\frac{-0.04645}{(-8.85)^{* * *}}$ & $\frac{-0.05509}{(-10.39)^{* * *}}$ \\
\hline$r_{t} \cdot p_{i t}$ & $\begin{array}{c}-0.00356 \\
(-5.93)^{* * *} \\
\end{array}$ & $\begin{array}{c}0.00252 \\
(3.41)^{* * *}\end{array}$ & $\begin{array}{c}0.00272 \\
(3.49)^{* * *}\end{array}$ & $\begin{array}{c}0.00315 \\
(2.67)^{* * *}\end{array}$ & $\begin{array}{c}0.00363 \\
(3.08)^{* * *}\end{array}$ \\
\hline \multicolumn{6}{|l|}{ Trad. services: } \\
\hline$p_{i t}$ & $\frac{-0.02961}{(-20.71)^{* * *}}$ & $\begin{array}{l}0.05189 \\
(27.75)^{* * *}\end{array}$ & $\begin{array}{l}0.05360 \\
(26.27)^{* * *}\end{array}$ & $\begin{array}{l}0.04590 \\
(12.21)^{* * *}\end{array}$ & $\begin{array}{l}0.03993 \\
(10.18)^{* * *}\end{array}$ \\
\hline$c_{t}$ & $\begin{array}{c}0.02348 \\
(6.56)^{* * *}\end{array}$ & $\begin{array}{c}-0.03326 \\
(-8.83)^{* * *}\end{array}$ & $\begin{array}{c}-0.03036 \\
(-6.35)^{* * *}\end{array}$ & $\frac{-0.12216}{(-12.31)^{* * *}}$ & $\begin{array}{l}-0.10255 \\
(-10.97)^{* * *}\end{array}$ \\
\hline$c_{t} \cdot p_{i t}$ & $\begin{array}{c}-0.00254 \\
(-3.18)^{* * *}\end{array}$ & $-\underset{(-0.03)}{0.00003}$ & -0.00069 & -0.00022 & $\begin{array}{c}-0.00342 \\
(-1.61)\end{array}$ \\
\hline$r_{t}$ & $\begin{array}{c}0.01232 \\
(3.39)^{* * *}\end{array}$ & $\underset{(0.94)}{0.00400}$ & $-\underset{(-1.51)}{0.00717}$ & $\underset{(-7.85)^{* * *}}{-0.07147}$ & $\frac{-0.07206}{(-7.70)^{* * *}}$ \\
\hline$r_{t} \cdot p_{i t}$ & $\begin{array}{c}0.00010 \\
(0.12)\end{array}$ & $\begin{array}{c}-0.00284 \\
(-2.90)^{* * *}\end{array}$ & $\begin{array}{c}-0.00205 \\
(-1.88)^{*} \\
\end{array}$ & $\begin{array}{c}-0.00532 \\
(-2.57)^{* *}\end{array}$ & $\begin{array}{c}-0.00707 \\
(-3.35)^{* * *}\end{array}$ \\
\hline \multicolumn{6}{|l|}{ Non T. services: } \\
\hline$p_{i t}$ & $\frac{-0.02981}{(-41.99)^{* * *}}$ & $\begin{array}{l}0.04239 \\
(48.72)^{* * *}\end{array}$ & $\begin{array}{l}0.03981 \\
(41.47)^{* * *}\end{array}$ & $\begin{array}{l}0.07020 \\
(39.44)^{* * * *}\end{array}$ & $\begin{array}{l}0.06401 \\
(33.16)^{* * *}\end{array}$ \\
\hline$c_{t}$ & $\begin{array}{l}0.02692 \\
(14.32)^{* * *}\end{array}$ & $\begin{array}{c}-0.04352 \\
(-19.87)^{* * *}\end{array}$ & $\frac{-0.04161}{(-19.00)^{* * *}}$ & $\frac{-0.08741}{(-22.19)^{* * *}}$ & $\begin{array}{c}-0.07259 \\
(-20.05)^{* * * *}\end{array}$ \\
\hline$c_{t} \cdot p_{i t}$ & $\begin{array}{c}-0.00204 \\
(-4.98)^{* * *}\end{array}$ & $\begin{array}{c}0.00172 \\
(3.58)^{* * *}\end{array}$ & $\begin{array}{c}0.00141 \\
(2.94)^{* * *}\end{array}$ & $\begin{array}{c}-0.00176 \\
(-1.98)^{* *}\end{array}$ & $\begin{array}{c}-0.00328 \\
(-3.95)^{* * *}\end{array}$ \\
\hline$r_{t}$ & $\begin{array}{l}0.01938 \\
(10.42)^{* * *}\end{array}$ & $\begin{array}{c}-0.00285 \\
(-1.50)\end{array}$ & $\frac{-0.01555}{(-7.17)^{* * * *}}$ & $\frac{-0.05815}{(-16.11)^{* * *}}$ & $\frac{-0.05631}{(-15.18)^{* * *}}$ \\
\hline$r_{t} \cdot p_{i t}$ & $\begin{array}{c}-0.00102 \\
(-2.55)^{* *}\end{array}$ & $\begin{array}{c}-0.00081 \\
(-1.93)^{*}\end{array}$ & $\begin{array}{c}-0.00018 \\
(-0.38)\end{array}$ & $\begin{array}{c}-0.00351 \\
(-4.28)^{* * *}\end{array}$ & $\begin{array}{c}-0.00410 \\
(-4.82)^{* * *}\end{array}$ \\
\hline Observations & $1,821,361$ & $2,044,591$ & $1,672,489$ & $2,044,591$ & $1,672,489$ \\
\hline Industry FE & Yes & Yes & Yes & Yes & Yes \\
\hline Sector FE & Yes & Yes & Yes & Yes & Yes \\
\hline Crisis FE & Yes & Yes & Yes & Yes & Yes \\
\hline
\end{tabular}

Note: Exit, employment and capital growth are measured from period t to period $t+1$. Regression for exit is a linear probability model where exit $=1$ if the firm is in the dataset in period $\mathrm{t}$ but not in period $\mathrm{t}+1 ; p_{i t}$ stands for $\log$ firm-level TFP; $c_{t}$ is a dummy variable equal to one for years 2011-2012 and $r_{i t}$ is a dummy variable equal to one for years 2013-2015. T-statistics (in parentheses) are obtained using standard errors clustered by industry; ${ }^{* * *} p<0.01$, $* *<0.05$, and ${ }^{*} p<0.10$ 
services, respectively. ${ }^{21}$

Table 7: Changes in the probability of exit during the crisis

\begin{tabular}{|l|c|c|c|}
\hline \hline & $\begin{array}{c}\text { Average } \\
\text { firm }\end{array}$ & $\begin{array}{c}\text { Low } \\
\text { productivity } \\
\text { firm }\end{array}$ & $\begin{array}{c}\text { High } \\
\text { productivity } \\
\text { firm }\end{array}$ \\
\hline \hline \multicolumn{1}{|c|}{$(1)$} & $(2)$ & $(3)$ & $(4)$ \\
\hline \hline Manufacturing & 0.77 & 1.41 & 0.12 \\
T Services & 1.29 & 1.64 & 0.93 \\
NT services & 1.85 & 2.19 & 1.51 \\
\hline Total Economy & 1.74 & 2.08 & 1.40 \\
\hline \hline
\end{tabular}

Note: Change in the probability of exit (percentage points) during the crisis period (20112012) vis-à-vis the pre-crisis period (2006-2010). Figures are computed from models estimated in Tables 5 and 6 The average firm is a firm with TFP equal to the corresponding sectoral mean. A low (high) productivity firm is a firm with productivity 1 standard deviation (s.d.) below (above) this mean.

Using the results in column (2) of Tables 5 and 6, we can compute the changes in the probability of exit for different types of firms. Table 7 records the change in the probability of exit during the crisis for an average firm, a low-productivity firm and a high-productivity firm operating in each of the three sectors of activity. ${ }^{22}$ Two interesting conclusions emerge. First, the increase in the probability of exit during the crisis is clearly lower in the tradable sector (manufacturing and tradable services) in line with the idea that this two sectors performed better than the nontradable sector during the crisis. Second, the increase in the probability of exit is clearly smaller for high-productivity firms in the three sectors, highlighting again the idea that the cleansing effect was present in all sectors of the economy 23 But we can characterize this cleansing effect even further. Table 8 shows the impact on the probability of exit

\footnotetext{
${ }^{21}$ To our knowledge, this is the first study to uncover this interesting result of a larger increase of the protective role of TFP in the manufacturing sector, during the crisis. It would be interesting to know if for other countries productivity also has a more protective role in the service than in the manufacturing sector, and how this protective role evolves during crises in both sectors.

${ }^{22}$ The average firm is defined as the firm with TFP equal to the corresponding sectoral mean. A low (high) productivity firm is a firm with productivity 1 standard deviation (s.d.) below (above) this mean.

${ }^{23}$ Note that in the context of our estimated models, the absence of a cleansing effect would imply that the change in the probability of exit would be the same for low- and high-productivity firms in the sector.
} 
associated with the cleansing effect for the different types of firms ${ }^{24}$ We see that, for the overall economy, the presence of a cleansing effect during the crisis reduced the probability of exit by 1.54 p.p. for high-productivity firms and by 0.56 p.p for lowproductivity firms. The corresponding figures for the manufacturing sector are 2.05 p.p and 0.76 p.p., respectively, confirming that this sector witnessed the highest cleansing impact regarding exiting firms.

Table 8: Changes in the probability of exit due to the cleansing effect

\begin{tabular}{|l|c|c|c|}
\hline \hline & $\begin{array}{c}\text { Average } \\
\text { firm }\end{array}$ & $\begin{array}{c}\text { Low } \\
\text { productivity } \\
\text { firm }\end{array}$ & $\begin{array}{c}\text { High } \\
\text { productivity } \\
\text { firm }\end{array}$ \\
\hline \hline \multicolumn{1}{|c|}{$(1)$} & $(2)$ & $(3)$ & $(4)$ \\
\hline \hline Manufacturing & -1.40 & -0.76 & -2.05 \\
T Services & -1.06 & -0.71 & -1.42 \\
NT services & -0.84 & -0.50 & -1.18 \\
\hline Total Economy & -0.90 & -0.56 & -1.54 \\
\hline \hline
\end{tabular}

Note: Differences in the probability of exit (percentage points) during the crisis period (20112012) vis-à-vis the pre-crisis period (2006-2010). Figures are computed from models estimated in Tables 5 and 6 with and without the coefficient of $c_{t} . p_{i t}$ set equal to zero. The average firm is a firm with TFP equal to the corresponding sectoral mean. A low (high) productivity firm is a firm with productivity 1 standard deviation (s.d.) below (above) this mean.

\subsection{Reallocation of inputs}

We now look at the relationships between productivity and input (employment and capital) growth. Under the cleansing hypothesis, the correlation between productivity and employment and capital growth should strengthen, as low-productivity firms should shrink more than high-productivity firms, in response to negative shocks. By contrast, under the scarring hypothesis, recessions are expected to weaken those relationships, so that the link between productivity and employment and/or productivity and capital growth should be attenuated. The results of the estimated models are

\footnotetext{
${ }^{24}$ Figures in Table 8 are obtained as the difference in the probability of exit with and without the coefficient of $c_{t} \cdot p_{i t}$ set equal to zero.
} 
in Tables 5 and 6 (columns (3) to (6)). Regressions for overall input growth (survivors+exit) and conditional growth (conditional on survival) are considered, so that the possibility of the results for input growth being driven by the exit margin is taken into account.

Table 5 shows that TFP has a positive and significant impact on employment and capital growth, irrespective of whether one looks at overall growth or survival growth, and, from Table 6, we conclude that this strong positive impact is common to the manufacturing and the two service sub-sectors. Table 5 also shows that, for the overall economy, there is a strengthening of the correlation between TFP and employment growth during the crisis (the coefficient of $c_{t} \cdot p_{i t}$ is positive and significant), that is, the positive impact of productivity on employment growth increased during the crisis. In contrast, the positive impact of capital growth decreases, i.e., there is an attenuation of the correlation between TFP and capital growth, during the crisis.

From Table6, however, we conclude that the cleansing effects regarding employment are particularly strong in manufacturing (also significant, but smaller in the nontradable services and not significant at all in tradable services). ${ }^{25}$ The sector-level results regarding capital reallocation are also very interesting, as they show that the overall attenuation effect of the crisis, recorded in Table 5, stems almost exclusively from the nontradable services sub-sector (for the other two sub-sectors, there is a non-significant weakening of the relationship in the tradable services and a non-significant strengthening in the manufacturing sector) ${ }^{26}$ Comparing the relationships during the crisis and the recovery periods allows a very interesting conclusion: the small and non significant strengthening of the relationship during the crisis in the manufacturing sector increases

\footnotetext{
${ }^{25}$ Recently, Carreira and Teixeira (2016) investigated the cleansing effects of the Portuguese financial crisis, using data for the manufacturing sector up to 2012. Their results differ from ours in that they found a scarring effect for exit (the interaction term in a type (4) equation is positive) and a negative impact of productivity on employment growth. The authors, however, consider 2008-2012 as the crisis period (there is also no recovery period) and include additional regressors in the estimated model, but do not include dummy variables for the different sub-periods, which may explain the divergence in the results.

${ }^{26}$ Note that the total economy considered in Table 5 , besides the three sectors considered in Table 6. also includes agriculture and construction. Thus, in rigor, the aggregate scarring effect of the crisis on capital reallocation in Table 5 also reflects developments in these two sectors.
} 
and becomes significant during the recovery period, while the small attenuation effect in the service sector during the crisis (but larger in the nontradable sector) also increases and becomes significant during the recovery period. Thus, manufacturing emerges as the only sector with intensified productivity enhancing reallocation regarding both employment and capital during the crisis and recovery periods. To put it slightly different, during the crisis and recovery periods, the importance of productivity as a determinant of firm input growth (both labour and capital) increased in the manufacturing sector but decreased in the service sector.

We believe that some specific features of the Portuguese crisis, together with structural differences between the sectors, underlie the sector-level heterogeneity regarding labour and capital reallocation, documented in this section. In particular, the significant weakening of the relationship between productivity and input growth in the nontradable service sub-sector, in contrast with the manufacturing sector, must reflect the fact that nontradable services (together with the construction sector), as shown in subsection 2.2 , were most affected by the sharp decline in domestic demand and the significant increase in the degree of lending restrictiveness during the Portuguese recession period, together with the presence in this sector of larger distortions or frictions that make resource reallocation more difficult (higher input adjustment costs and higher output-price rigidity in the context of lower competition) ${ }^{27}$

\section{$5.3 \quad$ Entry}

We now look at firm entry and investigate how the average productivity of new firms behaved during and after the crisis relative to the pre-crisis period. For that purpose, we estimate the simple linear probability model given by equation (4) for new firms, i.e., the dependent variable is a dummy variable that equals 1 if the firm is an entrant

\footnotetext{
${ }^{27}$ Related to this issue, Dias et al. (2019) show that misallocation, defined in the context of the Hsieh and Klenow approach (Hsieh and Klenow (2009)) is significantly higher in services than in manufacturing. They conclude that differences in the impact and size of productivity shocks explain most of the misallocation gap between the two sectors, and interpret their results as stemming from higher output-price rigidity, higher labour adjustment costs and higher informality in the service sector.
} 
and zero otherwise. Table 9 summarizes the results for the aggregate economy and the three main sectors of activity.

Table 9: Entry during the crisis and TFP

\begin{tabular}{|l|c|c|c|c|}
\hline \hline Covariates & $\begin{array}{c}\text { Total } \\
\text { Economy }\end{array}$ & Manuf. & $\begin{array}{c}\text { Tradable } \\
\text { services }\end{array}$ & $\begin{array}{c}\text { Nontradable } \\
\text { services }\end{array}$ \\
\hline \hline$(1)$ & $(2)$ & $(3)$ & $(4)$ & $(5)$ \\
\hline \hline constant & 0.26881 & 0.20175 & 0.28125 & 0.29584 \\
$p_{i t}$ & $(135.08)^{* * *}$ & $(40.85)^{* * *}$ & $(53.27)^{* * *}$ & $(111.64)^{* * *}$ \\
& -0.05221 & -0.03853 & -0.05455 & -0.05908 \\
$c_{t}$ & $(-113.50)^{* * *}$ & $(-34.10)^{* * *}$ & $(-44.71)^{* * *}$ & $(-95.29)^{* * *}$ \\
& -0.00595 & -0.00495 & -0.00912 & -0.00554 \\
$c_{t} \cdot p_{i t}$ & $(-6.20)^{* * *}$ & $(-2.65)^{* * *}$ & $(-3.69)^{* * *}$ & $(-4.33)^{* * *}$ \\
$r_{t}$ & -0.00032 & 0.00068 & -0.00154 & 0.00020 \\
& $(-1.52)$ & $(1.62)$ & $(-2.61)^{* * *}$ & $(0.74)$ \\
$r_{t} \cdot p_{i t}$ & 0.00279 & 0.00106 & -0.00435 & 0.00577 \\
& $(3.13)^{* * *}$ & $(0.62)$ & $(-1.92)^{*}$ & $(4.85)^{* * *}$ \\
Observations & -0.00053 & 0.00103 & -0.00203 & -0.00022 \\
Industry FE & $(-2.79)^{* * *}$ & $(2.78)^{* * *}$ & $(-3.83)^{* * *}$ & $(-0.88)$ \\
\hline \hline
\end{tabular}

Note: Regression for entry is a linear probability model where entry=1 if the firm is in the dataset in period $\mathrm{t}+1$ but not in period $\mathrm{t}$; $p_{i t}$ stands for $\log$ firm-level TFP; $c_{t}$ is a dummy variable equal to one for years 2011-2012 and $r_{i t}$ is a dummy variable equal to one for years 2013-2015. T-statistics (in parentheses) obtained using standard errors clustered by industries; ${ }^{* * *} p<0.01,{ }^{* *}<0.05$, and ${ }^{*} p<0.10$.

A first important conclusion is that higher productivity firms are less likely to be entrants. The estimated effect is statistically significant and relatively large. This result is common to the three sectors of activity, even though somewhat stronger in the two service sub-sectors compared to the manufacturing sector. Thus, entrants have, on average, lower productivity than incumbents, especially in the service sector. These findings are in line with the negative contribution of entrants documented in the previous subsection 28

There is also evidence of a significant decline in the probability of a firm being an entrant during the crisis (the coefficient of $c_{t}$ is negative), on the aggregate and for each of the three sectors of activity, as could be expected. In terms of the interaction between TFP and the crisis and recovery dummies, at the aggregate level (column

\footnotetext{
${ }^{28}$ Note, however, that this pattern may reflect lower prices for new firms compared to incumbents, as discussed in Appendix A.
} 
2), we do not find evidence of a significant change in entrants productivity relative to that of survivors during the crisis, but there seems to be a small deterioration during the recovery period. However, the disaggregation by sectors of activity uncovers an important contrast between the manufacturing sector on the one side and the two service sub-sectors on the other: in the manufacturing sector, entrants during the recovery period (less so during the crisis period) were relatively more productive than before the crisis, in contrast with the service sub-sectors, where entrants either emerge as less productive during and after the crisis (tradable services) or do not exhibit a significant change (nontradable services). In summary, according to Table 9 there seems to be no significant evidence that entrants during the crisis or the recovery period are, on average, more productive than in the pre-crisis period, except in the manufacturing sector 29

\subsection{Financial dependence and firm dynamics}

During financial crises credit market distortions may reduce the efficiency of resource reallocation through reduced bank lending to profitable projects that require more capital. Under these circumstances, high-productivity firms may exit because they are financially constrained. Bank forbearance is another channel through which credit market restrictions may distort resource reallocation, especially if banks are tempted to fund low-productivity firms, so that they look artificially solvent (zombie lending). This way banks can avoid reporting loan losses in their balance sheets. If these effects prevailed in the economy, we should witness an attenuation of the link between productivity and survival due to the exit of high-productivity firms in the first case, or reduced exit of low-productivity firms in the second case.

Our empirical evidence so far suggests that, on average, the Portuguese crisis was

\footnotetext{
${ }^{29}$ At first sight, this finding does not seem fully compatible with the evidence in the previous section, where we found a cleansing effect of entrants during the crisis. One must note, however, that the contributions in Table 4 are weighted averages, while the estimates in Table 9 are obtained from non-weighted regressions. The combined evidence in Tables 4 and 9 thus suggests that, during the crisis, the most productive firms, among entrants, were also the largest ones.
} 
productivity enhancing as we found no evidence of an aggregate attenuation effect regarding exit. However, this finding does not preclude the possibility of there being a significant number of firms that exit the market for the reasons pointed above. In fact, in the previous subsection we found evidence of an attenuation of the correlation between productivity and capital growth, as well as an increase in the probability of exit of high-productivity firms suggesting that the impact of credit constraints may have increased during the crisis. Thus, it is natural to ask whether the cleansing effect, documented above for exiting firms, would have been higher in the absence of increased credit constraints or credit forbearance during the crisis.

To answer this question, we investigate whether there is evidence of a higher probability of exit in industries where firms display higher external financial needs, and whether this probability has increased during and/or after the crisis.

We measure financial dependence at the industry level following the approach in Rajan and Zingales (1998). Data on firm's external financing (short term and long term banking debts) are available in our dataset. However, these data are not usable as they are expected to reflect the equilibrium between the demand for external funds and its supply. Since the latter is exactly what we are trying to test for, this information is contaminated. The approach in Rajan and Zingales (1998) assumes that there is a technological reason why some industries depend more on external finance than others (for example, because initial project scale, the gestation period, the requirement to continue investing etc., differ significantly between industries). In measuring external finance, we are interested in the amount of desired investment that cannot be financed through internal cash flows generated by the same business. Therefore, we define the financial dependence indicator as the capital expenditures minus the cash flow from operations divided by capital expenditures. To avoid simultaneity issues, we compute the indicator using data for 2006 and 2007 (pre-crisis years) ${ }^{30}$

\footnotetext{
${ }^{30}$ Time-invariant measures of external dependence at the industry level are arguably exogenous to the performance of individual firms over time, which is the source of variation in our regression.
} 
The estimated model, which is a generalization of equation (4), is the following:

$$
\begin{aligned}
y_{i, t+1}= & \lambda+\beta p_{i t}+\delta c_{t}+\gamma c_{t} \cdot p_{i t}+\mu r_{t}+\theta r_{t} \cdot p_{i t} \\
& +\rho_{1} c_{t} \cdot f_{s t}+\rho_{2} r_{t} \cdot f_{s t}+\rho_{3} f_{s t} \cdot p_{i t}+\rho_{4} c_{t} \cdot f_{s t} \cdot p_{i t}+\rho_{5} r_{t} \cdot f_{s t} \cdot p_{i t}+\epsilon_{i t}
\end{aligned}
$$

where $f_{s t}$ stands for the industry-level financial dependence indicator and the other covariates are defined as before. The coefficients $\rho_{i}(\mathrm{i}=1, . .4)$ capture the impact of the financial dependence indicator on the probability of exit. In particular, $\rho_{4}$, if positive, signals the presence of scarring effects of the crisis stemming from changing credit conditions 31

The estimated models, recorded in Table 10, show a strong contrast between the tradable and the nontradable sectors of the economy. The probability of exit during the crisis increases for firms operating in industries with higher financial dependence that belong to the nontradable sector (the coefficient of $c_{t} . f_{s t}$ is positive), but not for firms operating in industries that belong to the tradable sector (manufacturing and tradable services). For firms of the nontradable sector, there is also evidence that, for a given level of productivity, the probability of exit increases with the degree of financial dependence (the coefficient of $f_{s t} \cdot p_{i t}$ is positive and significantly different from zero) but, again, this is not the case of the tradable sector. Finally, and more importantly, there is no evidence of a crisis scarring effect stemming from the presence of financial dependence. The coefficient of $c_{t} \cdot f_{s t} \cdot p_{i t}$ is not significantly different from zero for any of the three sub-sectors considered, which means that the probability of exit in financially dependent industries is not more (positively) correlated with TFP

\footnotetext{
${ }^{31}$ Equation (5) is consistent with a theoretical model where firms facing credit constraints maximize profits in a monopolistic competitive environment (see Eslava et al. (2015)). Differently from Eslava et al. (2015)), however, who use an explicit measure of firm-level credit barriers, we use the interaction terms $f_{s t} \cdot p_{i t}$ to account for the possibility of firms being heterogeneous in their access to credit within industries. For a given level of industry financial needs, firms with higher TFP are expected to face less strict barriers in accessing credit. We note also that, to the extent that our TFP measure is a revenue and not a quantity productivity measure, our model implicitly accounts for idiosyncratic demand shocks and idiosyncratic distortions that may affect the probability of exit on dimensions other than credit. See the discussion on quantity versus revenue productivity in Appendix A.
} 
Table 10: Firm exit, TFP and capital needs

(Financial Dependence)

\begin{tabular}{|c|c|c|c|c|}
\hline Covariates & $\begin{array}{c}\text { Total } \\
\text { Economy }\end{array}$ & Manufact. & $\begin{array}{l}\text { Tradable } \\
\text { Services }\end{array}$ & $\begin{array}{c}\text { Nontradable } \\
\text { Services }\end{array}$ \\
\hline (1) & $(2)$ & (3) & & \\
\hline constant & $\begin{array}{l}0.16870 \\
(73.35)^{* * *}\end{array}$ & $\begin{array}{l}0.10694 \\
(20.55)^{* * *}\end{array}$ & $\begin{array}{l}0.19365 \\
(30.79)^{* * *}\end{array}$ & $\begin{array}{l}0.20422 \\
(66.96)^{* * *}\end{array}$ \\
\hline$p_{i t}$ & $\frac{-0.02177}{(-39.58)^{* * * *}}$ & $\underset{(-7.55)^{* * *}}{-0.01163}$ & $\frac{-0.03289}{(-42.15)^{* * *}}$ & $\frac{-0.02993}{(-39.58)^{* * *}}$ \\
\hline$c_{t}$ & $\begin{array}{l}0.02614 \\
(18.41)^{* * *}\end{array}$ & $\underset{(6.33)^{* * *}}{0.02292}$ & $\begin{array}{c}0.02368 \\
(5.68)^{* * *}\end{array}$ & $\begin{array}{l}0.02559 \\
(13.61)^{* * *}\end{array}$ \\
\hline$c_{t} \cdot p_{i t}$ & $\frac{-0.00189}{(-5.91)^{* * *}}$ & $\frac{-0.00268}{(-3.15)^{* * *}}$ & $\frac{-0.00282}{(-2.76)^{* * *}}$ & $\frac{-0.00157}{(-3.83)^{* * *}}$ \\
\hline$r_{t}$ & $\begin{array}{l}0.01903 \\
(13.50)^{* * * *}\end{array}$ & $\begin{array}{c}0.01212 \\
(3.37)^{* * *}\end{array}$ & $\frac{0.01027}{(2.47)^{* *}}$ & $\begin{array}{l}0.01947 \\
(10.47)^{* * *}\end{array}$ \\
\hline$r_{t} \cdot p_{i t}$ & $\begin{array}{c}-0.00171 \\
(-5.52)^{* * *}\end{array}$ & $\begin{array}{c}-0.00284 \\
(-3.38)^{* * *}\end{array}$ & $\begin{array}{c}0.00054 \\
(0.53)\end{array}$ & $\begin{array}{c}-0.00101 \\
(-2.46)^{* *}\end{array}$ \\
\hline$c_{t} \cdot f_{s t}$ & $\begin{array}{c}0.00488 \\
(2.57)^{* *}\end{array}$ & $\begin{array}{c}0.00595 \\
(1.07)\end{array}$ & $\begin{array}{c}-0.00083 \\
(-0.24)\end{array}$ & $\begin{array}{c}0.01191 \\
(4.07)^{* * *}\end{array}$ \\
\hline$r_{t} \cdot f_{s t}$ & $-\underset{(-0.44)}{0.00084}$ & $\begin{array}{c}-0.00228 \\
(-0.40)\end{array}$ & $\begin{array}{c}-0.00316 \\
(-0.92)\end{array}$ & $-\underset{(-0.37)}{-0.00111}$ \\
\hline$f_{s t} \cdot p_{i t}$ & $\underset{(5.13)^{* * *}}{0.00426}$ & $\frac{-0.00835}{(-3.05)^{* * *}}$ & $\begin{array}{c}-0.00701 \\
(-3.54)^{* * *}\end{array}$ & 0.00878 \\
\hline$c_{t} \cdot f_{s t} \cdot p_{i t}$ & $\begin{array}{c}0.00040 \\
(0.93)\end{array}$ & $\underset{(1.11)}{0.00165}$ & $\begin{array}{c}-0.00039 \\
(-0.45)\end{array}$ & $-\underset{(-1.64)}{0.00105}$ \\
\hline$r_{t} \cdot f_{s t} \cdot p_{i t}$ & $\begin{array}{c}0.00060 \\
(1.40)\end{array}$ & $\begin{array}{c}0.00193 \\
(1.29)\end{array}$ & $\begin{array}{c}0.00067 \\
(0.79)\end{array}$ & $\begin{array}{c}0.00068 \\
(1.03)\end{array}$ \\
\hline Observations & $1,821,361$ & 255,099 & 292,813 & $1,005,992$ \\
\hline Industry FE & Yes & Yes & Yes & Yes \\
\hline
\end{tabular}

Note: Regression for exit is a linear probability model where exit=1 if the firm is in the dataset in period $\mathrm{t}$ but not in period $\mathrm{t}+1 ; p_{i t}$ stands for $\log$ firm-level TFP and $f_{s t}$ for the industry-level financial dependence indicator; $c_{t}$ is a dummy variable equal to one for years 2011-2012 and $r_{i t}$ is a dummy variable equal to one for years 2013-2015. T-statistics (in parentheses) obtained using standard errors clustered by industries; ${ }^{* *} p<0.01$, ${ }^{* *}<0.05$, and ${ }^{*} p<0.10$.

during the crisis than it was in the pre-crisis period. A similar conclusion holds for the recovery period. Thus, we do not find evidence that the cleansing effect detected in our baseline regressions, regarding exiting firms, would have been significantly higher in the absence of increased credit constraints or credit forbearance during the crisis ${ }^{32}$

\footnotetext{
${ }^{32}$ Recently, Blattner et al. (2018) investigate the implications of the regulatory intervention by the European Banking Authority on Portuguese banks in 2011. This intervention increased capital requirements for a subset of banks and the authors conclude that exposed banks cut back on credit to all but a subset of financially distressed firms for which banks had been underreporting incurred loan losses. Using the Petrin and Levinsohn (2012) decomposition the authors estimate that credit reallocation accounts for close to 20 percent of the decline in productivity in 2012 . We note, that the finding in Blattner et al. (2018) is not necessarily inconsistent with the conclusions of this subsection, because we investigate the probability of exit in financially dependent industries during the crisis, while Blattner et al. (2018) investigate the impact of reduced credit on output/productivity of surviving firms. For these firms, as we have seen above, there is evidence of scarring effects regarding capital
} 
The evidence in this subsection is also relevant in that it corroborates the idea of a stark contrast between the tradable and nontradable sectors, in line with the evidence in the previous subsections. The absence of a significant scarring effect of credit restrictions on exiting firms, documented here, implies that credit restrictions, to the extent that they underlie the negative capital reallocation documented in subsection 5.2, must have affected mainly surviving firms of the nontradable services sub-sector.

\section{Conclusions}

Whether crises have a cleansing or a scarring effect is important for economic policy. If crises are cleansing, policies aimed at containing short-term negative impacts may obstruct long-run recovery and thus be counterproductive. But, if crises are scarring, policies that mitigate short-term impacts may contribute to maximize long-term efficiency. Economic theory suggests that whether recessions have a cleansing or a scarring effect depends on the type and importance of distortions prevailing in the economy. But, the impact of recessions on resource reallocation and productivity is also expected to vary with the type of shocks hitting the economy, as these may have different firmand industry-level implications.

One limitation of previous studies is that, due to data-availability, they are restricted to the manufacturing sector. However, manufacturing contributes less than 20 percent to total GDP and has very different characteristics from the service sector, the largest sector of the economy, which precludes generalizations to the rest of the economy. This paper adds to the literature by bringing forward novel evidence on the consequences of crises on resource reallocation and productivity, involving the various sectors of the economy.

Using microlevel data for the Portuguese economy, we investigate how the patterns of resource reallocation changed during the Portuguese financial crisis (2011-2012),

reallocation and, moreover, a significant decrease in the contribution to productivity growth took place during the crisis. 
in particular, the extent to which they were productivity enhancing and long-lasting. With this purpose in mind, we decompose aggregate productivity measures according to the contributions of the different groups of firms (surviving, entering and exiting firms) and estimate regressions on exit, entry and input growth, by sectors of activity (manufacturing, tradable and nontradable services).

We find that the financial crisis in Portugal had an overall cleansing effect, both in manufacturing and services, but there were significant differences regarding the impact on the patterns of resource reallocation in the two sectors. This conclusion follows from the aggregate productivity decompositions performed both for labour productivity and TFP, as well as from the firm-level regressions estimated for TFP. From the aggregate productivity decompositions, we find higher positive contributions for productivity growth of the between-firm and exiting components, together with a lower negative contribution of entry, with an overall positive impact on productivity growth. From firm-level regressions on TFP, we find that the crisis reduced the probability of survival for high- and low-productivity firms, but hit low-productivity firms disproportionately harder, in line with the cleansing hypothesis. However, the protective impact of productivity increased significantly more in relative terms in manufacturing than in the service sector. In the manufacturing sector, new firms also emerge as relatively more productive during and after the crisis, in contrast with the service sector.

From firm level regressions, we also find that more productive firms are more likely to grow, but the crisis impacted the reallocation of labour and capital differently: the correlation between productivity and employment growth strengthened, but the correlation between productivity and capital growth weakened. However, these aggregate results reflect very different sectoral developments, with the manufacturing sector exhibiting cleansing effects for both employment and capital reallocation (especially the former), and the service sector, especially nontradable services, exhibiting a significant weakening of the correlation between productivity and capital changes.

The cleansing effect documented for the crisis period was, by and large, a short- 
lived phenomenon. With the exception of the contribution for productivity growth of exiting firms, possibly due to lagged effects of the crisis, the increase in productivity contributions recorded for other components during the crisis, either completely vanished or declined substantially during the recovery period.

Finally, we find that the probability of exiting increased for firms operating in more financially dependent industries that belong to the nontradable services sub-sector, but there is no significant evidence of an attenuation effect. In other words, we did not find evidence that the cleansing impact, regarding exiting firms, would have been higher in the absence of increased credit constraints during the crisis.

Overall, our results suggest that crises may have qualitatively different effects on different sectors of the economy, depending on the combination of the type and size of shocks hitting the economy with the type and importance of distortions and frictions prevailing in each sector. In the limit, crises may have a cleansing effect for some sectors, but scarring effects for others. Ultimately, it is crucial to have data for the whole economy to assess the true impact of crises on aggregate productivity dynamics.

Our analysis is mostly descriptive - evaluating how the patterns of resource reallocation changed over the 2011-2012 Portuguese financial crisis. In particular, this paper does not explicitly addresses why changes in reallocation patterns differed across sectors of activity. We believe, however, that some specific features of the Portuguese crisis, together with structural differences between the sectors underlie the sector-level heterogeneity regarding input reallocation and productivity growth. In particular, the significant weakening of the relationship between productivity and capital growth, documented for the nontradable services sub-sector, in contrast with the manufacturing sector, must reflect the presence in that sector of larger distortions or frictions that make resource reallocation more difficult (higher input adjustment costs and higher output-price rigidity in the context of lower competition). But to provide more convincing evidence on the reasons behind this sector-level heterogeneity, we would need to find ways to integrate direct measures of the demand and credit shocks into a model 
with frictions, defined at the firm or at least the sectoral level.

\section{References}

Amador, J. and Soares, A. C. (2012), Competition in the Portuguese economy: An overview of classical indicators, Working Paper 8, Banco de Portugal.

Baily, M., Hulten, C. and Campbell, D. (1992), 'Productivity dynamics in manufacturing plants', Brookings Papers on Economic Activity: Microeconomics 4, 187 267.

Barlevy, G. (2002), 'The sullying effect of recessions', The Review of Economic Studies 69(1), 65-96.

Barlevy, G. (2003), 'Credit market frictions and the allocation of resources over the business cycle', Journal of Monetary Economics 50(8), 1795 - 1818.

Bartelsman, E. and Dhrymes, P. J. (1998), 'Productivity dynamics: U.S. manufacturing plants, 1972-1986', Journal of Productivity Analysis 9, 5-34.

Belke, A., Oeking, A. and Setzer, R. (2015), 'Domestic demand, capacity constraints and exporting dynamics: Empirical evidence for vulnerable euro area countries', Economic Modelling 48, 315-325.

Blanchard, O. (2007), 'Adjustment within the euro. The difficult case of Portugal', Portuguese Economic Journal 6(1), 1-21.

Blanchard, O. and Portugal, P. (2017), Boom, slump, sudden stops, recovery, and policy options. Portugal and the Euro, Working Papers 11-2017, Banco de Portugal.

Blattner, L., Farinha, L. and Rebelo, F. (2018), When losses turn into loans: The cost of undercapitalized banks, Working Paper 16, Banco de Portugal. 
Caballero, R. J. and Hammour, M. L. (1994), 'The cleansing effect of recessions', The American Economic Review 84(5), 1350-1368.

Caballero, R. J. and Hammour, M. L. (1996), 'On the timing and efficiency of creative destruction', The Quarterly Journal of Economics 111(3), 805-852.

Carreira, C. and Teixeira, P. (2016), 'Entry and exit in severe recessions: lessons from the 2008-2013 Portuguese economic crisis', Small Business Economics 46(4), 591617.

Casacuberta, C. and Gandelman, N. (2015), 'Productivity, exit, and crisis in the manufacturing and service sectors', The Developing Economies 53(1), 27-43.

Collier, P. and Goderis, B. (2009), Structural policies for shock-prone developing countries, CSAE Working Paper Series 2009-03, University of Oxford.

Dias, D. A., Marques, C. R. and Richmond, C. (2016), 'Misallocation and productivity in the lead up to the Eurozone crisis', Journal of Macroeconomics 49, 46-70.

Dias, D. A., Marques, C. R. and Richmond, C. (2019), 'A tale of two sectors: Why is misallocation higher in services than in manufacturing?', The Review of Income and Wealth (forthcoming).

Diewert, W. E. (1980), Aggregation problems in the measurement of capital, in D. Usher, ed., 'Measurement of Capital', Chicago: University of Chicago Press, chapter 8, pp. 433-528.

Eichenbaun, M., Rebelo, S. and de Resende, C. (2016), The Portuguese crisis and the IMF, Background Paper BP/16-02/05, IEO - Independent Evaluation Office of the IMF.

Ericson, R. and Pakes, A. (1995), 'Markov-perfect industry dynamics: A framework for empirical work', The Review of Economic Studies 62(1), 53-82. 
Eslava, M., Galindo, A., Hofstetter, M. and Izquierdo, A. (2015), Scarring recessions and credit constraints: Evidence from Colombian plant dynamics, mimeo.

Esteves, P. and Prades, E. (2018), 'Does export concentration matter in economic adjustment programs? Evidence from the euro-area', Economic Modelling 40, 225241.

Foster, L., Grim, C. and Haltiwanger, J. (2016), 'Reallocation in the great recession: Cleansing or not?', Journal of Labor Economics 34(S1), S293-S331.

Foster, L., Haltiwanger, J. and Krizan, C. J. (2001), Aggregate productivity growth: Lessons from microeconomic evidence, in 'New Developments in Productivity Analysis', ed. Carles R. Hulten, Edward R. Dean, and Michael J. Harper, Chicago and London: University of Chicago Press, chapter 8, pp. 303-372.

Foster, L., Haltiwanger, J. and Syverson, C. (2008), 'Reallocation, firm turnover, and efficiency: Selection on productivity or profitability?', 98, 394-425.

Ghandi, A., Navarro, S. and Rivers, D. (2016), On the identification of production functions: How heterogenous is productivity?, mimeo.

Griffin, N. N. and Odaki, K. (2009), 'Reallocation and productivity growth in Japan: Revisiting the lost decade of the 1990s', Journal of Productivity Analysis 31(2), 125136.

Griliches, Z. and Regev, H. (1995), 'Firm productivity in Israeli industry 1979-1988', Journal of Econometrics 65(1), 175 - 203.

Hallward-Driemeier, M. and Rijkers, B. (2013), 'Do crises catalyze creative destruction? Firm-level evidence from Indonesia', The Review of Economics and Statistics 95(5), 1788-1810.

Haltiwanger, J., Scarpeta, S. and Schweiger, H. (2008), Assessing job flows across 
countries: The role of industry, firm size and regulations, Working Paper 13920, NBER.

Hopenhayn, H. A. (1992), 'Entry, exit, and firm dynamics in long run equilibrium', Econometrica 60(5), 1127-1150.

Hsieh, C.-T. and Klenow, P. J. (2009), 'Misallocation and manufacturing TFP in China and India', The Quarterly Journal of Economics 124(4), 1403-1448.

Jovanovic, B. (1982), 'Selection and the evolution of industry', Econometrica 50(3), 649-670.

Kehrig, M. (2015), The cyclical nature of the productivity distribution, mimeo, Duke University.

Levinsohn, J. and Petrin, A. (2003), 'Estimating production functions using inputs to control for unobservables', The Review of Economic Studies 70(2), 317-341.

Liu, L. and Tybout, J. R. (1996), Productivity growth in Chile and Colombia: The role of entry, exit, and learning, in 'Industrial Evolution in Developing Countries', Mark J. Roberts and James R. Tybout edn, Oxford University Press, chapter 4, pp. $73-103$.

Melitz, M. J. and Polanec, S. (2015), 'Dynamic Olley-Pakes productivity decomposition with entry and exit', The RAND Journal of Economics 46(2), 362-375.

Mortensen, D. T. and Pissarides, C. A. (1994), 'Job creation and job destruction in the theory of unemployment', The Review of Economic Studies 61(3), 397-415.

Nishimura, K. G., Nakajima, T. and Kiyota, K. (2005), 'Does the natural selection mechanism still work in severe recessions?: Examination of the Japanese economy in the 1990s', Journal of Economic Behavior \& Organization 58(1), 53 - 78.

OECD (2017), Labour Market Reforms in Portugal 2011-2015, A Preliminary Assessment, Organization for Economic Co-operation and Development, Paris. 
Olley, G. S. and Pakes, A. (1996), 'The dynamics of productivity in the telecommunications equipment industry', Econometrica 64(6), 1263-1297.

Osborne, J. W. (2002), 'Notes on the use of data transformation', Practical Assessment, Research and Evaluation 8(6).

Osborne, J. W. and Overbay, A. (2004), 'The power of outliers (and why researchers should always check for them)', Practical Assessment, Research and Evaluation 9(6).

Osotimehin, S. and Pappadà, F. (2017), 'Credit frictions and the cleansing effect of recessions', The Economic Journal 127(602), 1153-1187.

Ouyang, M. (2009), 'The scarring effect of recessions', Journal of Monetary Economics $\mathbf{5 6}(2), 184-199$.

Petrin, A. and Levinsohn, J. (2012), 'Measuring aggregate productivity growth using plant-level data', RAND Journal of Economics 43(4), 705-725.

Rajan, R. G. and Zingales, L. (1998), 'Financial dependence and growth', The American Economic Review 88(3), 559-586.

Reis, R. (2013), 'The Portuguese slump and crash and the euro crisis', Brookings Papers on Economic Activity 46(1, Spring), 143-210.

Schumpeter, J. A. (1939), Business Cycles: A Theoretical, Historical, and Statistical Analysis of the Capitalist Process, 2 vols edn, New York: MacGraw Hill.

Schumpeter, J. A. (1942), Capitalism, Socialism and Democracy, New York: Harper.

Wooldridge, J. M. (2009), 'On estimating firm-level production functions using proxy variables to control for unobservables', Economics Letters 104, 112-114. 


\section{Appendix A: Measuring productivity at the firm level}

This Appendix describes the details regarding the definition of our two productivity measures, including the discussion of some estimation, interpretation, and aggregation issues. The labour productivity measure is defined as the log difference of real value added and employment (number of employees), and TFP is computed as the estimated residuals of a three input Cobb-Douglas production function:

$$
\ln T F P_{i t}=\ln Q_{i t}-\alpha_{K} \ln K_{i t}-\alpha_{L} \ln L_{i t}-\alpha_{M} \ln M_{i t}
$$

where $\mathrm{Q}$ is real gross output, $\mathrm{K}$ is real capital, $\mathrm{L}$ is the number of employees, and $\mathrm{M}$ is real intermediate consumption.

The elasticities $\alpha_{j}(j=K, L, M)$ are estimated at the industry level using the Levinsohn-Petrin estimator (see Levinsohn and Petrin (2003)), to account for the endogeneity of the regressors (inputs). Note that this estimation method does not impose constant returns to scale (CRS), and, based on our estimates, CRS is rejected for a large number of industries 33

TFP is our preferred measure of productivity. Labor productivity is easy to calculate and interpret, but its main drawback is that it can be a biased indicator when a resource-substitution effect exists. In fact, under the assumption of constant returns to scale (for ease of presentation), equation (A1) can be rewritten as:

$$
\ln \left(Q_{i t} / L_{i t}\right)=\ln T F P_{i t}+\alpha_{K} \ln \left(K_{i t} / L_{i t}\right)+\alpha_{M} \ln \left(M_{i t} / L_{i t}\right)
$$

which shows that changes in labour productivity may stem from changes in TFP, but also from changes in capital intensity or/and intermediate consumption intensity. Thus, reallocation of employment towards high labour productivity firms may arise from a

\footnotetext{
${ }^{33}$ As robustness checks, we also computed TFP using the OLS estimates and the input shares. The qualitative conclusions obtained in this paper for these alternative TFP measures do not depend on the estimation method used.
} 
shift towards more capital intensive firms, rather than from a reallocation of resources towards high TFP firms. The use of TFP as a measure of productivity, however, also raises important issues, as it is not observable and it must be estimated conditional on a given production function and on specific econometric estimators.

\section{Quantity versus revenue productivity}

An important issue regarding the computation of firm-level productivity is how to compute real gross output (or real value added) at the firm level. As firm-level prices are unobserved, real gross output at the firm level is obtained by using an industrylevel price deflator to deflate nominal output. The implication is that our productivity measure obtained from equation (A1) is a revenue measure and not a physical or quantity productivity measure (this is na issue that is common in this literature that generally uses industry-level price deflators and is not specific to our analysis) ${ }^{34}$ If firms face a differentiated product environment, we may expect an inverse relationship between physical productivity and firm-level prices. In such a case, our measure of productivity, obtained from equation (A1), will tend to underestimate the physical productivity of more productive firms (because such firms tend to charge lower prices). A similar phenomenon may occur with young firms. The evidence in the literature (see Foster et al. (2008)) suggests that young firms also tend to charge lower prices relative to older firms. This depresses the measurement of the physical output of entrants relative to incumbents and thus, may affect the results for the productivity decompositions (namely the relative contribution of entrants). After all, our measure of firm-level productivity should be interpreted as reflecting not only technical efficiency but also any other factors (like demand factors) that translate into firm-level prices.

Another important consequence occurs in the environment of monopolistic com-

\footnotetext{
${ }^{34}$ Revenue productivity, $T F P R_{i t}$, is defined as price times quantity productivity, i.e., $T F P R_{i t}=$ $P_{i t} T F P_{i t}$ where $P_{i t}$ stands for the firm-level output price. If we use the industry-level price index, $\bar{P}_{t}$, to deflate nominal gross output, instead of $\ln T F P_{i t}$ on the right-hand side of equation (A1), we will get $\ln \left(T F P R_{i t}^{*}\right)=\ln \left(\left(P_{i t} T F P_{i t}\right) / \bar{P}_{t}\right)$, which corresponds to revenue productivity of firm i up to a scalar, $\bar{P}_{t}$, common to all firms in the industry.
} 
petition with a CRS Cobb-Douglas production function, as considered in Hsieh and Klenow (2009). In this case, changes in efficiency (i.e., quantity productivity) yield a proportional decline in prices, and in equilibrium, revenue productivity (TFPR) is constant across firms in the industry. In such a framework, TFPR differences across firms signal misallocation of resources stemming from distortions on input prices and/or frictions like adjustment costs of inputs or output-price rigidities ${ }^{35}$ Firms with higher TFPR are interpreted as facing higher distortions, so that changes in TFPR may signal changes in TFP but also changes in distortions. These are important aspects that must be kept in mind when evaluating some of the results presented in this paper or any similar paper using industry-price deflators.

\section{Appendix B: Computing aggregate productivity us- ing firm-level productivities}

To get industry-level or economy-wide average productivity measures, we need to choose the weights, $\theta_{i t}$, to be used in equation (11). When aggregating (averaging) labour productivity measures, employment (or hours worked) emerges as the natural choice as it allows reproducing exactly average productivity that we get from aggregate industry data, i.e., dividing industry-level output by industry-level employment. However, sometimes gross output or gross value added have also been used as weights (as a complement or as an alternative to employment) to obtain aggregate measures of labour productivity (see Foster et al. (2001), Griffin and Odaki (2009), HallwardDriemeier and Rijkers (2013)).

When aggregating (averaging) firm-level TFP at the industry- or sector-level, two essentially distinct types of weights have been used: the gross-output or value-added (real or nominal) shares (Baily et al. (1992), Foster et al. (2001), Olley and Pakes (1996), Griffin and Odaki (2009), Hallward-Driemeier and Rijkers (2013), Melitz and

${ }^{35}$ See, Dias et al. $(2016$, ,2019) for a detailed discussion and an application to Portugal. 
Polanec (2015)) and the input-mix shares (Liu and Tybout (1996) and Bartelsman and Dhrymes (1998)). Important empirical results, involving the components of the productivity decompositions discussed in this paper, have been shown to depend on the choice of the weights (see, for instance, Foster et al. (2001) and Griffin and Odaki $(2009))$, so that it is important to discuss the pros and cons of their use.

Let us assume the industry $s$ with $\mathrm{N}$ firms, where the firm-level production function is assumed to be Cobb-Douglas:

$$
Y_{i}=T F P_{i} K_{i}^{\alpha} L_{i}^{\beta}, \quad i=1,2, . ., N
$$

Following the literature, the industry-level production function is defined as:

$$
Y_{s}=T F P_{s} K_{s}^{\alpha} L_{s}^{\beta}
$$

where $X_{s}=\sum_{i=1}^{N} X_{i}, \quad X=Y, K, L$ and $T F P_{s}$ is, by definition, industry-level average TFP ${ }^{37}$ From A4, we can now express $T F P_{s}$ as follows:

$$
T F P_{s}=\frac{Y_{s}}{K_{s}^{\alpha} L_{s}^{\beta}}=\frac{\sum_{i}^{N} Y_{i}}{K_{s}^{\alpha} L_{s}^{\beta}}=\sum_{i}^{N}\left(\frac{K_{i}}{K_{s}}\right)^{\alpha}\left(\frac{L_{i}}{L_{s}}\right)^{\beta} T F P_{i}=\sum_{i}^{N} \theta_{i}^{*} T F P_{i}
$$

Equation A5 shows that in order to recover $T F P_{s}$ using firm-level productivity, $\left(T F P_{i}\right)$, one should use weights $\theta_{i}^{*}=\left(K_{i}^{\alpha} L_{i}^{\beta}\right) /\left(K_{s}^{\alpha} L_{s}^{\beta}\right)$. A minor problem with this approach, however, is that, due to nonlinear aggregation, the weights $\theta_{i}^{*}$ will not, in general, add up to one exactly, which is a condition required in the above decompositions. In order to overcome this problem, we may define instead

$$
T F P_{s}^{*}=\sum_{i}^{N} \frac{K_{i}^{\alpha} L_{i}^{\beta}}{\sum_{i}^{N} K_{i}^{\alpha} L_{i}^{\beta}} T F P_{i}=\sum_{i}^{N} \theta_{i} T F P_{i}
$$

\footnotetext{
${ }^{36}$ For ease of presentation, here we stick to a value-added production function with two inputs, but nothing would change if a gross-output production function with three inputs were used, instead.

${ }^{37}$ See, for instance, Hsieh and Klenow (2009).
} 
where the weights:

$$
\theta_{i}=\frac{K_{i}^{\alpha} L_{i}^{\beta}}{\sum_{i}^{N} K_{i}^{\alpha} L_{i}^{\beta}}
$$

add up to one. For the purpose of the present paper the $\theta_{i}$ are denoted as the input-mix shares. We have $\theta_{i}^{*}=\theta_{i}$ if and only if $\sum_{i}^{N} K_{i}^{\alpha} L_{i}^{\beta} /\left(K_{s}^{\alpha} L_{s}^{\beta}\right)=1$, but in practice, we do not expect weights $\theta_{i}$ and $\theta_{i}^{*}$ to differ significantly from each other ${ }^{38}$ Thus, using the weights $\theta_{i}$ in equation (1) generates aggregate (average) TFP measures that closely match average aggregate productivity, as defined in equation A4 . But what if output shares are used as weights, instead, as is also common in the literature ${ }^{39}$ If we use value added shares as the weights to compute aggregate productivity, we get (using equation (A3)):

$$
T F P_{s}^{* *}=\sum_{i}^{N} \frac{Y_{i}}{\sum_{i}^{N} Y_{i}} T F P_{i}=\sum_{i}^{N} \frac{T F P_{i}}{T F P_{s}^{*}} \theta_{i} T F P_{i}=\sum_{i}^{N} \theta_{i}^{* *} T F P_{i}
$$

where $\theta_{i}^{* *}=\frac{T F P_{i}}{T F P_{s}^{*}} \theta_{i}$ and $T F P_{s}^{*}$ is given by $\mathrm{A} 6$.

Equation (A8) differs from equation $(\mathrm{A} 6 \mathrm{~T}$ in some important dimensions. First, we note that equation (A8) does not match the definition of aggregate productivity, presented in (A4), as closely as equation (A6) does. The weights $\theta_{i}^{* *}$, which are a combination of the inputs used, $\left(\theta_{i}\right)$, and of the firm-level relative productivity $\left(T F P_{i} / T F P_{s}^{*}\right)$, imply that firms with productivity above average productivity (as given by equation (A6)) receive higher weights and firms with productivity below average receive lower weights than implied by the amount of inputs used. This is likely to make (A8) a biased estimator of aggregate productivity in comparison with (A4): if on average larger firms

\footnotetext{
${ }^{38}$ It is easy to show that $\sum_{i}^{N} K_{i}^{\alpha} L_{i}^{\beta} /\left(K_{s}^{\alpha} L_{s}^{\beta}\right)=1$ if capital intensity is the same for all firms in the industry $\left(K_{i} / L_{i}=K_{j} / L_{j}\right)$ and there are constant returns to scale.

${ }^{39}$ The use of gross-output or gross value-added shares to compute aggregate TFP can be motivated in the context of a competitive environment with CRS production functions, where firms face the same output and input prices. Diewert (1980) (section 8.5.3) shows that under such conditions the appropriate weight for each firm is their share of industry revenue (nominal gross output or nominal value added) which is equivalent to their share of industry real gross output or real value added.
} 
are more productive than smaller firms (with size measured by the amount of labour or capital inputs), we expect larger firms to receive disproportionately higher weights and smaller firms disproportionately smaller weights compared to equations (A5) or (A6). Second, $T F P_{s}^{* *}$ is expected to be more sensitive to measurement errors than $T F P_{s}^{*}$. A positive outlier in output will yield a spuriously high positive change in $T F P_{i}$ and in the share, $\theta_{i}^{* *}$, but $\theta_{i}$ is not affected by the measurement error. In turn, a positive measurement error in employment (or capital) reduces $T F P_{i}$, but the corresponding increase in the weights in the $T F P_{s}^{*}$ case creates a compensation effect that is not present in $T F P_{s}^{* *}$. Thus, measures that use output shares as weights (gross output or value added) are expected to make firm-level contributions more sensitive to the presence of measurement errors ${ }^{40}$ Finally, which we believe is an important drawback, the use of $T F P_{s}^{* *}$ makes the interpretation of the productivity decompositions presented in equation (3), in the main text, less clear-cut. In particular, the interpretation of the between and cross effects (and thus, of the within effects) is blurred by the fact that changes in the weights can be the result of changes in productivity $\left(T F P_{i}\right)$ and not the result of resource (input) reallocation across firms (changes in $L_{i}$ or $K_{i}$ ).

The above discussion justifies our preference for the use of the input-mix shares as the weights in our aggregate TFP measures. However, as a robustness check we also compute an aggregate TFP measure using gross output shares as weights.

But, of course, the above discussion does not prevent our aggregate productivity measures, and especially the individual components of the corresponding decompositions (cross, between and within terms) of being individually affected by the presence of measurement errors in the relevant variables (gross output and inputs). Thus, in order to further attenuate the impact of outliers on our aggregate productivity measures and their decompositions, we use the shares of log employment and of log "input mix" as weights to compute aggregate labour productivity and aggregate TFP measures,

\footnotetext{
${ }^{40}$ In a similar manner, aggregate labour productivity with employment shares as weights is less sensitive to measurement errors (outliers in employment or output) than aggregate labour productivity with output shares as weights.
} 
respectively.

The use of the log transformation has been suggested as an alternative to trimming or winsorizing to deal with outliers. By permitting extreme values to be kept in the data set, it avoids the uncertainty associated with the choice of the trimming or winsorizing thresholds. The use of the log transformation has also been suggested as way to correct for the skewness of positively skewed distributions (see Osborne (2002) and Osborne and Overbay (2004)). The log transformation compresses the distribution of the weights around the "average" firm, reducing the importance of the largest firms and increasing the importance of the smallest firms. In an industry (or economy) characterized by the presence of many small firms and a few very large firms (right skewed distribution), this transformation may prevent aggregate productivity measures from being fully dominated by productivity developments of a small number of big firms.

In summary, by using the shares of log employment or log input mix as weights, we generate aggregate productivity measures that a) may be thought of as yielding the productivity developments of a "representative" or "average" firm and b) are robust to outliers (measurement errors) affecting inputs (employment, capital stock or intermediate inputs).

\section{Appendix C: Measuring the capital stock}

To compute TFP we need a measure of the real capital stock. In our dataset, we have information on the book values of the net capital stock, which are not adequate for our purposes. Thus, we use the perpetual inventory method to calculate the capital stock. Specifically, we compute the real capital stock according to the following formula (for firm $i$ in industry $s$ ) :

$$
K_{i s t}=\left(1-\delta_{s}\right) K_{i s, t-1}+\left(I_{i s t} / P I_{t}\right)
$$


where $I_{i s t}$ denotes gross fixed capital formation, $\delta_{s}$ is the industry level depreciation rate and $P I_{t}$ is the investment goods deflator. However, for firms that started to operate before 2006 (the first year of our dataset), we correct the initial capital stock by a sector-specific adjustment coefficient that varies according to the age of the firm. Suppose that two firms in the data set in 2006, one that is 10 years old and the other that is just 2 years old. The book values of capital are not comparable because they refer to different generations of capital that were bought in different years and at different prices. Thus, simply deflating the book values of the capital stock in the first year of the sample for all firms, irrespective of their age, introduces an important measurement error in the real capital stock. We used information on the book values of the capital stock and investment from other data sources for a large sample of firms and apply the inventory method starting in the first year of operation of such firms. ${ }^{41}$ This allows us to construct an industry-specific adjustment coefficient (ratio of real capital stock to the book-values capital stock) that varies according to the age of the firm, and that is used to estimate the firm-level real capital stock in $2006{ }^{42}$

\footnotetext{
${ }^{41}$ The data sources are from Instituto Nacional de Estatística (INE), the Portuguese Statistics Institute, and covers the period 1996 to 2005. The source of the information for the 1996-2004 subperiod is the Inquérito à Empresa Harmonizado (IEH), while for the 2004-2005 subperiod the information comes from the Sistema de Contas Integradas das Empresas (SCIE). The two sources of data provide very detailed information on the firm's balance sheet and income statement and were used in Dias et al. (2016).

${ }^{42}$ For firms that started to operate before 1996, we assume that this was their first year, as we do not have information before 1996 .
} 


\section{Appendix D: Additional productivity decompositions}

This Appendix provides additional macrolevel evidence on the cleansing impact of the Portuguese financial crisis. Tables A1 and A2 show the decompositions of our two productivity measures for tradable and nontradable services.

Tables A3, A4 and A5 show aggregate productivity measures for the total economy, manufacturing and services, based on a different set of weights. In these tables, aggregate labour productivity is computed using the shares of employment as weights, and TFP is computed using the shares of log nominal gross output (see Appendix B for a discussion on the use of gross output shares as alternative weights to compute aggregate TFP).

Table A1: Labour productivity decomposition: average annual contributions (Tradable and Nontradable Services)

\begin{tabular}{|l|c|c|c|c|c|c|}
\hline \hline \multirow{3}{*}{ Components } & \multicolumn{3}{|c|}{ Tradable Services } & \multicolumn{3}{c|}{ Nontradable Services } \\
\cline { 2 - 7 } & $\begin{array}{c}\text { Pre-crisis } \\
(2006-2010)\end{array}$ & $\begin{array}{c}\text { Crisis } \\
(2011-2012)\end{array}$ & $\begin{array}{c}\text { Recovery } \\
(2013-2015)\end{array}$ & $\begin{array}{c}\text { Before } \\
(2006-2010)\end{array}$ & $\begin{array}{c}\text { Crisis } \\
(2011-2012)\end{array}$ & $\begin{array}{c}\text { Recovery } \\
(2013-2015)\end{array}$ \\
\hline \hline$(1)$ & $(2)$ & $(3)$ & $(4)$ & $(5)$ & $(6)$ & $(7)$ \\
\hline \hline Surviving firms & -1.56 & -9.22 & -0.48 & 1.24 & -2.10 & 3.22 \\
Within & 0.29 & -7.61 & 1.66 & 2.55 & -1.44 & 4.41 \\
Between & 2.86 & 2.77 & 2.42 & 2.22 & 2.51 & 2.12 \\
Cross & -4.71 & -4.38 & -4.56 & -3.53 & -3.17 & -3.31 \\
\hline Net-entry & -1.02 & 0.55 & 0.06 & -1.70 & -0.42 & -1.13 \\
Entry & -2.62 & -1.49 & -1.82 & -3.55 & -3.23 & -4.12 \\
Exit & 1.60 & 2.05 & 1.88 & 1.85 & 2.81 & 2.99 \\
\hline Total reallocation & -2.87 & -1.06 & -2.08 & -3.01 & -1.08 & -2.32 \\
\hline Total change & -2.58 & -8.67 & -0.42 & -0.46 & -2.52 & 2.09 \\
\hline \hline
\end{tabular}

Note: Labour productivity refers to value added per employee; the weights are the shares of log employment; the service sector does not include construction nor utilities (electricity, gas and water services). 
Table A2: TFP decomposition: average annual contributions (Tradable and Nontradable Services)

\begin{tabular}{|l|c|c|c|c|c|c|}
\hline \hline & \multicolumn{3}{|c|}{ Tradable Services } & \multicolumn{3}{c|}{ Nontradable Services } \\
\cline { 2 - 7 } Components & $\begin{array}{c}\text { Pre-crisis } \\
(2006-2010)\end{array}$ & $\begin{array}{c}\text { Crisis } \\
(2011-2012)\end{array}$ & $\begin{array}{c}\text { Recovery } \\
(2013-2015)\end{array}$ & $\begin{array}{c}\text { Pre-crisis } \\
(2006-2010)\end{array}$ & $\begin{array}{c}\text { Crisis } \\
(2011-2012)\end{array}$ & $\begin{array}{c}\text { Recovery } \\
(2013-2015)\end{array}$ \\
\hline \hline$(1)$ & $(2)$ & $(3)$ & $(4)$ & $(5)$ & $(6)$ & $(7)$ \\
\hline \hline Surviving firms & -0.59 & -3.22 & 0.45 & -0.10 & -0.82 & 1.40 \\
Within & -0.59 & -3.11 & 0.57 & 0.23 & -0.52 & 2.17 \\
Between & 0.59 & 0.48 & 0.50 & 0.60 & 0.72 & 0.57 \\
Cross & -0.59 & -0.59 & -0.62 & -0.93 & -1.02 & -1.34 \\
\hline Net-entry & 1.41 & 2.58 & 2.62 & -1.67 & 0.05 & -0.56 \\
Entry & 1.24 & 1.89 & 1.86 & -3.34 & -2.34 & -2.93 \\
Exit & 0.16 & 0.69 & 0.76 & 1.66 & 2.39 & 2.38 \\
\hline Total reallocation & 1.41 & 2.47 & 2.50 & -2.00 & -0.25 & -1.33 \\
\hline Total change & 0.82 & -0.64 & 3.07 & -1.77 & -0.77 & 0.84 \\
\hline
\end{tabular}

Note: TFP refers to gross output with weights given by the shares of log "input mix". The service sector does not include construction nor utilities (electricity, gas and water services).

Table A3: Productivity decompositions: average annual contributions (Total economy)

\begin{tabular}{|l|c|c|c|c|c|c|}
\hline \hline & \multicolumn{2}{|c|}{ Labour Productivity } & \multicolumn{3}{c|}{ TFP } \\
\cline { 2 - 6 } Components & $\begin{array}{c}\text { Pre-crisis } \\
(2006-2010)\end{array}$ & $\begin{array}{c}\text { Crisis } \\
(2011-2012)\end{array}$ & $\begin{array}{c}\text { Recovery } \\
(2013-2015)\end{array}$ & $\begin{array}{c}\text { Pre-crisis } \\
(2006-2010)\end{array}$ & $\begin{array}{c}\text { Crisis } \\
(2011-2012)\end{array}$ & $\begin{array}{c}\text { Recovery } \\
(2013-2015)\end{array}$ \\
\hline \hline$(1)$ & $(2)$ & $(3)$ & $(4)$ & $(5)$ & $(6)$ & $(7)$ \\
\hline \hline Surviving firms & -0.13 & -1.69 & 0.83 & -0.20 & -1.43 & 1.43 \\
Within & 1.54 & -0.85 & 2.76 & -0.40 & -1.79 & 1.09 \\
Between & 1.42 & 2.38 & 1.35 & -0.18 & -0.15 & -0.19 \\
Cross & -3.09 & -3.22 & -3.28 & 0.38 & 0.51 & 0.53 \\
\hline Net-entry & -0.22 & 0.33 & -0.03 & -1.03 & 0.16 & 0.33 \\
Entry & -2.17 & -2.05 & -2.27 & -1.32 & -0.72 & -0.89 \\
Exit & 1.95 & 2.37 & 2.24 & 0.29 & 0.88 & 1.22 \\
\hline Total reallocation & -1.89 & -0.51 & -1.96 & -0.83 & 0.52 & 0.67 \\
\hline Total change & -0.35 & -1.36 & 0.80 & -1.23 & -1.27 & 1.76 \\
\hline \hline
\end{tabular}

Note: Labour productivity refers to value added per employee, using the shares of employment as weights; TFP refers to gross output, using the shares of log nominal gross output as weights. 
Table A4: Labour productivity decomposition: average annual contributions (Manufacturing and Services)

\begin{tabular}{|l|c|c|c|c|c|c|}
\hline \hline & \multicolumn{3}{|c|}{ Manufacturing } & \multicolumn{3}{c|}{ Services } \\
\cline { 2 - 7 } Components & $\begin{array}{c}\text { Pre-crisis } \\
(2006-2010)\end{array}$ & $\begin{array}{c}\text { Crisis } \\
(2011-2012)\end{array}$ & $\begin{array}{c}\text { Recovery } \\
(2013-2015)\end{array}$ & $\begin{array}{c}\text { Before } \\
(2006-2010)\end{array}$ & $\begin{array}{c}\text { Crisis } \\
(2011-2012)\end{array}$ & $\begin{array}{c}\text { Recovery } \\
(2013-2015)\end{array}$ \\
\hline \hline$(1)$ & $(2)$ & $(3)$ & $(4)$ & $(5)$ & $(6)$ & $(7)$ \\
\hline \hline Surviving firms & 1.67 & -0.02 & 1.55 & -0.50 & -2.68 & 0.88 \\
Within & 1.82 & 0.05 & 1.96 & 1.76 & -1.60 & 3.19 \\
Between & 1.30 & 1.29 & 0.93 & 1.44 & 2.69 & 1.42 \\
Cross & -1.45 & -1.36 & -1.34 & -3.70 & -3.77 & -3.73 \\
\hline Net-entry & 0.67 & 1.21 & 0.20 & -0.48 & -0.19 & -0.14 \\
Entry & -1.24 & -1.15 & -1.66 & -2.36 & -2.29 & -2.28 \\
Exit & 1.91 & 2.36 & 1.85 & 1.88 & 2.10 & 2.15 \\
\hline Total reallocation & 0.52 & 1.14 & -0.21 & -2.74 & -1.27 & -2.45 \\
\hline Total change & 2.34 & 1.19 & 1.75 & -0.98 & -2.87 & 0.74 \\
\hline \hline
\end{tabular}

Note: Labour productivity refers to value added per employee; the weights are the shares of employment; The service sector does not include construction nor utilities (electricity, gas and water services).

Table A5: TFP decomposition: average annual contributions (Manufacturing and Services)

\begin{tabular}{|l|c|c|c|c|c|c|}
\hline \hline & \multicolumn{3}{|c|}{ Manufacturing } & \multicolumn{3}{c|}{ Services } \\
\cline { 2 - 7 } Components & $\begin{array}{c}\text { Pre-crisis } \\
(2006-2010)\end{array}$ & $\begin{array}{c}\text { Crisis } \\
(2011-2012)\end{array}$ & $\begin{array}{c}\text { Recovery } \\
(2013-2015)\end{array}$ & $\begin{array}{c}\text { Pre-crisis } \\
(2006-2010)\end{array}$ & $\begin{array}{c}\text { Crisis } \\
(2011-2012)\end{array}$ & $\begin{array}{c}\text { Recovery } \\
(2013-2015)\end{array}$ \\
\hline \hline$(1)$ & $(2)$ & $(3)$ & $(4)$ & $(5)$ & $(6)$ & $(7)$ \\
\hline \hline Surviving firms & 0.32 & -0.69 & 1.03 & -0.18 & -1.42 & 1.61 \\
Within & 0.04 & -1.32 & 0.62 & -0.42 & -1.80 & 1.29 \\
Between & 0.05 & 0.29 & 0.06 & -0.15 & -0.13 & -0.22 \\
Cross & 0.23 & 0.34 & 0.35 & 0.39 & 0.51 & 0.54 \\
\hline Net-entry & -0.68 & 0.67 & 1.42 & -0.88 & 0.61 & 0.41 \\
Entry & 1.14 & 1.40 & 1.60 & -2.04 & -1.16 & -1.48 \\
Exit & -1.83 & -0.73 & -0.18 & 1.15 & 1.77 & 1.88 \\
\hline Total reallocation & -0.40 & 1.30 & 1.83 & -0.64 & 0.99 & 0.73 \\
\hline Total change & -0.36 & -0.02 & 2.45 & -1.06 & -0.81 & 2.02 \\
\hline \hline
\end{tabular}

Note: TFP refers to gross output with weights given by the shares of log nominal gross output. The service sector does not include construction nor utilities (electricity, gas and water services). 